\title{
Havaalanlarında Müşteri Memnuniyetinin Sağlanması: Van Ferit Melen Havaalanı Örneği ${ }^{1}$
}

\section{Ensuring Customer Satisfaction at Airports: Van Ferit Melen Airport Example}

\author{
Mehtap KIPÇAK ${ }^{2}$ \\ Burak UYAR 3a \\ 2 2Yüksek Lisans Öğrencisi, Van Yüzüncü Yıl Üniversitesi, Fen Bilimleri Enstitüsü, İstatistik A.D, \\ a.kipcak34@gmail.com, ORCID: 0000-0001-5492-6771 \\ 3 3Öğretim Üyesi, Van Yüzüncü Yıl Üniversitesi, İktisadî ve İdari Bilimler Fakültesi, Ekonometri Bölümü, İstatistik \\ A.D. , burak.uyar@yyu.edu.tr, ORCID: 0000-0002-3178-4157 \\ aYazışılan yazar/Corresponding author
}

$\begin{array}{ll}\text { Article Info: } & \text { Research Article } \\ \text { Date Submitted: } & 06.11 .2021 \\ \text { Date Revised: } & 24.11 .2021 \\ \text { Date Accepted: } & 24.11 .2021\end{array}$

\section{Abstract}

Providing customer satisfaction in the right way in air transport, where there is a great increase in passenger demands today, is considered as a phenomenon that will accelerate the development in airline management. In our study, a survey was conducted with the voluntary participation of 300 customers among a total of 6000 passengers using Van Ferit Melen Airport within the specified date range, and their satisfaction and dissatisfaction were examined. It has been determined that income and education levels have an important place among the factors affecting the satisfaction of individuals traveling from Van Ferit Melen Airport, and occupational groups have a significant impact on the status of traveling from Van Ferit Melen Airport. Satisfaction status of airline customers and these situations It is aimed to improve the satisfaction elements in air passenger transportation by considering the factors that affect the customer, to eliminate the factors that cause dissatisfaction, to bring the identified issues to the literature and to evaluate the sector by the enterprises.

Anahtar Kelimeler: Airport management, Airport system, Customer satisfaction.

$\begin{array}{ll}\text { Makale Bilgisi: } & \text { Araştırma Makalesi } \\ \text { Geliş Tarihi: } & 06.11 .2021 \\ \text { DüzeltmeTarihi: } & 24.11 .2021 \\ \text { Kabul Tarihi: } & 24.11 .2021\end{array}$

Özet

Günümüzde yolcu talepleri açısından büyük bir artış yaşanan hava yolu taşımacılığında müşteri memnuniyetinin doğru şekilde sağlanabilmesi, havayollar işletmeciliğindeki gelişimi daha da hizlandiracak bir olgu olarak ele alınmaktadır. Çalışmamızda, belirlenen tarih aralı̆̆ında, Van Ferit Melen Havalimani'n kullanan toplam 6000 yolcu arasindan 300 müşterinin gönüllü katılımıyla anket yapılıp memnuniyet durumları incelenmiştir. Van Ferit Melen Havalimani'ndan seyahat eden bireylerin memnuniyetini etkileyen faktörlerin başında, gelir ve eğitim durumlarının önemli bir yere sahip olduğu, meslek gruplarının da Van Ferit Melen Havalimani'ndan seyahat etme durumu üzerinde önemli etkisinin olduğu tespit edilmiştir. Havayolu müşterilerinin memnuniyet durumları ve bu durumlar üzerinde etkili olan faktörlerin, müşteri gözünden ele alınarak havayolu yolcu taşımacılığındaki memnuniyet unsurlarının geliştirilmesi, memnuniyetsizliğe sebep olan unsurların ortadan kaldırlması, tespit edilen hususların literatüre kazandırılarak işletmeler tarafından değerlendirmeye alınıp sektörün daha iyi bir hale getirilmesi amaçlanmıştır.

Key Words: Havaalanı işletmeciliği, Havaalanı sistemi, Müşteri memnuniyeti

JEL kodlarn: M30, M31, R41 


\section{EXTENDED SUMMARY}

Aim of the Study: Ensuring customer satisfaction at airports, as in every business, is of great importance both for the continuity of the business and for the development of existing structures. However, as in every commercial activity, the necessity of individuals who benefit from this activity to be customers and to satisfy customers has also shown itself in air transportation. In this transportation system, where there was not much competition in the early periods, the existence of more than one airline company as of today and their expectations regarding customers brought customer satisfaction to the agenda. This element of satisfaction, which has emerged especially with airline management, is considered as one of the most important elements in terms of air transportation as of today. The main purpose of the study can be expressed as determining the factors that cause customer satisfaction or dissatisfaction in the field of airline passenger transportation, retaining the customers using the existing airline transportation, and in addition to these, gaining new customers to the airline transportation. In this context, research has been done on the customers who use Van Ferit Melen Airport in air transportation, their satisfaction and dissatisfaction have been examined and the reasons for these have been tried to be determined.

Research Questions: Providing customer satisfaction, which is so important for businesses, can be considered as a structure affected by many factors in connection with the complex structure of airports. As a matter of fact, issues such as focusing on the use of information technologies at airports, updating the services carried out in terms of human resources, and acting in accordance with both national and international standards regarding the services offered to customers due to the competition between existing airline transport companies appear as a necessity in terms of ensuring customer satisfaction. The prepared study seeks answers to the questions of determining the issues that affect the situation, satisfaction or dissatisfaction of the customers in air passenger transportation and bringing these determined issues into the literature and evaluating them by the enterprises and making the sector better.

Literature Review: Today, the increase in the number of companies operating in the field of air transport has brought a competitive environment in this field. This has resulted in airline companies showing activities aimed at customer satisfaction. Some studies on airports and airport systems in the literature in previous years; Kavzoğlu \& Y1lmaz (2005), Kaya (2005), Kesikbaş (2006), Koçel (1995), Gerede (2002). Şengür (2017) about the services provided at the airport, Tavmergen (2002), TOBB (2014) about the improvement of the airport service quality, Okumuş \& Asil (2007) about the passenger satisfaction in airport management, Burucuoğlu (2011), Odabaşı about the measurement of customer satisfaction. (2003), Seyidoğlu (2009), Koçel (2007), about statistical analyzes of customer satisfaction, İslamoğlu \& Alnıçık (2014) and Altunışık et al. (2012) are available in the literature.

Methodology: Providing customer satisfaction in the right way in air transport, where there is a great increase in passenger demands today, is considered as a phenomenon that will accelerate the development in airline management. Our research is philosophically fundamental, explanatory in terms of the aim pursued in the study, quantitative in terms of the method used, and an individual-level study in terms of analysis. In order to collect the data to be used in the analysis of the research, a survey was conducted with the voluntary 
participation of 300 customers among a total of 6000 passengers using Van Ferit Melen Airport, within the specified date range, and their satisfaction and dissatisfaction were examined.

Results - Conclusion: Considering that ensuring customer satisfaction is of vital importance for businesses, we should primarily mention that as a result of our research, we have reached a general conclusion that not only the services offered at the airport but also certain characteristics of the customers are effective, as a result of our research, in our study of ensuring customer satisfaction at Van Ferit Melen Airport. required. Based on the results of our research on this subject, it is possible to say that the main factors affecting the satisfaction of airline customers are the economic status of the customers and their educational status. In addition, it has been determined that the use of air transport has increased in direct proportion to the improvement in the economic situation of the customers, and in this direction, the level of travel at Van Ferit Melen Airport has increased. The level of reflection of the relationship between education level and customer satisfaction on Van Ferit Melen Airport again shows itself in the form of an increase in the frequency of use of airline transportation. 


\section{Giriş}

İnsanların bir yerden farklı bir yere gitmesi faaliyetini ifade eden ulaşım, bu yönüyle basit bir eylem olarak algılansa da insanların bulundukları bölgede, ülke içinde, ülkelerarası veya kıtalararası yaptığı ulaşım faaliyetleri göz önüne alındığında bu faaliyetin oldukça geniş kapsama sahip ve farklı özellikleri olan bir kavram olduğu anlaşılacaktır.

Ulaşım faaliyetleri ilk dönemleri itibariyle insanların yaya olarak gerçekleştirdiği faaliyetler olarak bilinmektedir. Ancak devam eden süreçte gerek mesafelerin uzaması gerekse insanların bu faaliyetler esnasında yanlarında farklı şeyleri de taşıma istekleri ulaşımda araçların kullanılmasını gündeme getirmiştir. Yine ilk dönemlerde bu ulaşım araçlarının, evcilleştirilen binek hayvanları gibi hayvanlar olduğu bilinmektedir. Bu bağlamda insanlar hayvanların evcilleştirilmesinin ardından onlarla yaptıkları ulaşım faaliyetlerini zaman içinde bu hayvanlara çektirilecek yeni araçlar icat edilmesi yoluyla daha gelişmiş bir hale getirmişlerdir. Özellikle ticaret faaliyetleri ile birlikte ticarete konu olan ürünlerin taşınması gerekliliği sonucunda büyük bir ivme kazandı̆̆ından bahsedilebilecek olan ulaşım faaliyetlerinin, bu yönüyle yeni araçların oluşturulması ve daha fazla malzemenin taşınmasına doğru gelişim gösterdiği kaydedilmektedir.

Ulaşım ilk dönemler açısından daha çok kara ulaşımı olarak değerlendirilse de insanların farklı coğrafyalara ulaşma isteği ile karşılaştıkları deniz, göl vb. doğal engelleri aşma arzusu, deniz yolu ulaşımını da geliştirmiş ve su üzerinde giden araçlarla malzeme taşınmaya ya da insanlar bir yerden bir yere gitmeye başlamışlardır. Ulaşımın geçirdiği bu değişimden zaman içinde insanların bireysel anlamdaki taleplerinin de ulaşım faaliyetleri ile çözülmesi hususu gündeme gelmiş ve gerek denizyolu gerekse karayolu aracılığıyla insanlar farklı yerlere gitmek için yeni ulaşım araçları kullanmaya başlamışlardır.

İnsanların ilk dönemler sahip oldukları araçlarla yaptıkları ulaşım faaliyeti devam eden dönemler açısından toplu ulaşım faaliyetlerine dönüşmeye başlamış ve bu da ulaşımın ayrı bir sektör olarak şekillenmeye başlamasını gündeme getirmiştir. Diğer bir ifade ile ilk dönemler kendi ihtiyaçlarını ya da ürünlerini taşıyan insanlar zaman içinde bir yerden bir yere gitmek için başka insanların ulaşım araçlarını kullanmaya başlamışlardır. Farklı insanların ulaşım araçlarının kullanılmaya başlaması ile taşıma faaliyetleri ulaşımında kendi içinde ticari bir yapısı olmasını ön plana çıkarmıştır. Ulaşım faaliyetlerinin zaman içinde hızlanmasına yönelik olarak yürütülen faaliyetlerle kara ulaşımında motorlu taşıtlar kullanıldığı gibi deniz ulaşımında da motorlu taşıtlar kullanılmıştır. Bununla birlikte daha fazla yük taşıyabilmek için insanların demiryolu ulaşımını kullandığı da kaydedilmektedir. Ancak ulaşımın bu yönü, ne şekilde olursa olsun insanların doğal engelleri aşması zorunluluğunu da beraberinde getirmiştir. Kara ulaşımında özellikle arazinin coğrafi yapısı en temel belirleyici olmakla birlikte bulunan coğrafyanın iklimi ve bu iklimin ulaşım konusunda oluşturduğu zorluklarda bir diğer etken olarak ön plana çıkmaktadır. Deniz ulaşımı ise sahil şehri olma özelliğine sahip olmayan alanlar için yalnızca geçici bir rahatlık sağlayabilmektedir. Bu noktada insanlar ulaşım faaliyetlerini daha kolay bir hale getirmek amacıyla kuşlardan esinlenerek uçarak ulaşım sağlamayı arayışına girmişlerdir.

$\mathrm{Bu}$ arayışlar sonrasında geliştirilen uçaklar ile ilk dönemler kısa mesafelerde daha az kişi ulaşım sağlayabilirken bu ulaşım türünün sağladığı yararlar değerlendirildiğinde hava taşımacılığına yönelim ve bu alanda profesyonel faaliyetleri gerçekleştirmek için hızlı 
adımlar atılmaya başlanmıştır. Özellikle uçakların geliştirilmesi noktasında atılan bu adımlar devam eden süreç içinde profesyonel hava ulaşımının ortaya çıkmasını ve hava ulaşımını yaygınlaşmasını gündeme getirmiştir.

Hava ulaşımında gelinen profesyonel nokta insanların bu ulaşım faaliyetlerini kullanabilmesi için belirli merkezlerinin oluşturulması ve yine bu merkezlerde hava ulaşım araçlarının havalanabilmesi ve inebilmesi için gerekli donanımların hazırlanması gibi bir gelişimi doğurmuştur. Havaalanı olarak adlandırılan bu yapılarda insanlar hava ulaşım araçlarını kullanabilmekte, biniş ve iniş, bagaj yükleme gibi faaliyetleri gerçekleştirmek ve bu şekilde sistemli bir yapı içinde ulaşım sağlamaktadırlar. Ancak her ticari faaliyette olduğu gibi bu faaliyetten istifade eden bireylerin müşteri olmaları, müşterilerin memnun edilmesi zorunluluğu hava ulaşımında da kendisini göstermiştir. İlk dönemler çok fazla rekabetin olmadığı bu ulaşım sisteminde, günümüz itibariyle birden fazla havayolu işletmesinin olması ve bunların müşterilerle ilgili olan beklentileri müşteri memnuniyetinin sağlanmasını gündeme getirmiştir. Özellikle havayolu işletmeciliği ile ortaya çıkan bu memnuniyet unsuru günümüz itibariyle havayolu taşımacılığı açısından en önemli unsurlardan biri olarak ele alınmaktadır.

\section{Literatür Özeti}

\subsection{Havaalanı ve havaalanı sistemi kavramlarının tanımlanması}

Havaalanı kavramı, ulaştırma sistemleri içinde alt birimler bünyesinde değerlendirilen hava taşımacılığı dahilinde yer alan alt yapı elemanlarından biri olarak kabul edilmektedir. Bu doğrultuda havaalanları, hava taşımacılığı noktasında kullanılacak tüm yapı ve ekipmanlarla donatılmış özel tesisler olarak tanımlanabilir. Bu yapı ve ekipmanlar içinde; hava araçlarının iniş - kalkış trafiği ve yolcu trafiğinin düzenlenmesi için kullanılacak binalar, hava araçlarının yapacağı uçuşlara hazırlık aşamasında gerekli bakım ve ikmal yapıları, uçuş sonrası iniş veya uçuş esnasındaki kalkışların sağlanması için gerekli donanımı içeren yapıları sıralamak mümkündür. Bu doğrultuda havaalanları karada veya su üzerinde yapılmış tesisler olması mümkün olmakla birlikte, bu tesislerin gerekli donanımlar ve hava araçlarının iniş kalkışı ile beraber yer hareketleri (manevraları) yaparken kullanabilecekleri belirli alanları ifade etmektedir (2920 Sayılı Türk Sivil Havacılık Kanunu, Resmî Gazete, 18196).

Havaalanlarının sahip olduğu ekipman veya donanımlar nedeni ile literatürde genel olarak özel alanlar şeklinde değerlendirildiğini görmek mümkündür (Kavzoğlu \& Yılmaz, 2005). Nitekim bu alanlar hem geniş bir fiziki çevreyi hem de büyük bir yatırım maliyetini gerekli kılmaktadır. Bu doğrultuda hava taşımacılığı noktasında kullanılacak teknolojik yapılarla birlikte bünyesinde barındırdığı mekanik ve elektronik sistemler ile havaalanlarının oldukça dinamik bir yapısının olduğu söylenebilir. Havaalanları yapı ve bünyesinde yer alan oluşumlarla oldukça büyük bir sistemi ifade etmektedir. Bu büyüklük nedeniyle bahsedilen sistemin birtakım alt sistem bileşenlerinin olduğu da bilinmektedir. Havaalanlarında yer alan alt sistemler genel olarak;

- havayolu bünyesinde faaliyet gösteren işletmeleri,

- ticari birimler,

- $\quad$ meydan işletme birimleri, 
- yer hizmeti veren kuruluşlar,

- $\quad$ havacilik otoriteleri,

- destek hizmeti sağlayan kuruluşlar,

- $\quad$ sivil havacılık kuruluşları,

- yolcular

olarak siralanmaktadır (Kaya, 2005: 14).

Havaalanlarının dinamik yapısı, sürekli olarak faaliyet gösteren alanlar olmalarına bağlı olmakla birlikte bu yapılar içinde kullanılan teknolojilerin sürekli bir değişim ve gelişim halinde olması ile de ilişkili olarak ele alınabilir. Nitekim havaalanları, faaliyet gösterdikleri alanda gelişen ve değişen teknolojiyi sürekli şekilde takip etmek zorunda olduğu için ekstra bir dinamik yapı kazanmaktadırlar. Bu gelişim unsuru yalnızca hava araçlarının gerektirdiği teknoloji kapsamında değerlendirilmemelidir. Günümüzde hava taşımacılığı alanında faaliyet gösteren işletmelerin sayısının artması bu alanda bir rekabet ortamını da beraberinde getirmiştir. $\mathrm{Bu}$ da havayolu şirketlerinin müşteri memnuniyetine yönelik faaliyetler göstermesi sonucunu doğurmuştur. Pek çok havayolu işletmesinin müşteri memnuniyetini bir ilke olarak benimsemesi sonucunda, havayolu işletmelerinin çoğunun bu alandaki teknolojilere de uyum sağlama konusunda belirli yönetim bilgi sistemlerine yöneldikleri kaydedilmektedir. Bununla birlikte bahsedilen yönetim bilgi sistemlerinin hem havaalanlarındaki işletme yöneticilerine hem de bu sistemlerden faydalanan son kullanıcılara önemli miktarda kolaylık sağladığı da ifade edilmektedir (Kesikbaş, 2006).

Havaalanı sistemi ise literatürde farklı şekillerde tanımlanan bir yapıyı ifade etmektedir. $\mathrm{Bu}$ sistemler genel manada ulusal ya da uluslararası alanda faaliyet gösteren hava taşımacılığ sisteminin vazgeçilmez bir parçası olarak değerlendirmektedir. Havaalanı sistemleri, faaliyet gösterilen bölgenin sosyal, kültürel ve ekonomik gelişimi noktasında büyük katkıları olan havaalanlarının, hizmet üretimi noktasında kullandıkları açık sistemler olarak ele alınmaktadır. Ancak bu sistemler havaalanlarının karmaşık yapısında olduğu gibi belirli parçalar ve alt sistemlerin bir araya gelmesiyle oluşan bütünsel bir yapıyı ifade etmektedir. Bu doğrultuda havaalanı sistemi olarak ifade edilen bütünsel yapının, bu bütünü meydana getiren parçalardan bağımsız bir şekilde hareket etmesi mümkünken, tüm bu parçalar arasında koordinasyon ve iletişimin sağlanmasını da mümkün kılması gerektiğine vurgu yapılmaktadır (Kaya, 2005: 19).

Farklı bir tanımlamada ise havaalanı sistemleri; havaalanları içinde daha önceden belirlenmiş olan hedeflerin gerçekleştirilmesi için belirli finans kaynaklarından alınan para, malzeme, araç, insan gücü vb. girdileri değerlendirerek, elde edilen tüm bu unsurların havaalanlarını kullanan kişilerin istek ve beklentilerine cevap verebilecek şekilde havaalanı hizmetlerine dönüştürülmesini sağlayan açık sistemler olarak tanımlanmaktadır (Koçel, 1995: 157). 


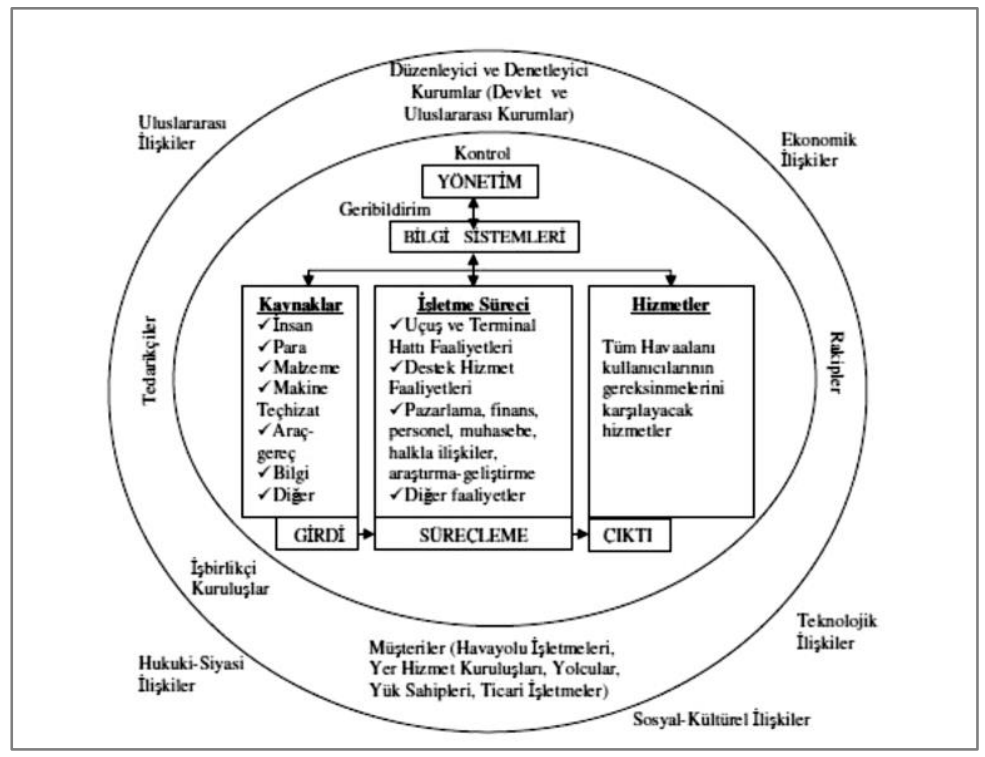

Şekil 2.1. Havaalanı sistemi ve dinamikleri (Gerede, 2002:17).

Şekilde de görüldügü gibi havaalanı sistemi, bir havaalanında mevcut bulunan bütün yapıları bünyesinde toplayan bir sistemi ifade etmektedir. $\mathrm{Bu}$ sistemin en tepesinde düzenleyici ve denetleyici kurumlar bulunmaktadır ki bunlar devlet kurumları ve uluslararası kurumlar olarak ayrılmaktadır. Bununla birlikte yine sistemin kapsayıcısı olarak uluslararası ilişkiler, ekonomik ilişkiler, teknolojik ilişkiler, hukuki - siyasi ilişkiler ve sosyal kültürel ilişkiler şeklinde sistemin ilişki içinde bulunacağı bütün yapılarda bir kapsayıcı olarak ele alınmıştır. Sistemin iç yapısında ise kontrol mekanizmasında yönetim ve yönetimin değerlendirdiği geri bildirim öğesi almaktadır. Geri bildirimler ise tam olarak bilgi sistemleri dahilinde bulunmakta; kaynaklar, işletme süreci ve hizmetler olarak ayrılan yapılardan alınan geri bildirimlere göre değerlendirme yapılmaktadır. Bu sistemde kaynaklar - girdi, işletme süreci - süreçleme, hizmetler ise çıktı olarak ifade edilmektedir (Kaya, 2000: 49 - 50).

\subsection{Havalimanlarında verilen hizmetler}

Havalimanlarında verilen hizmetlerin pek çoğu benzer olmakla birlikte havalimanı türüne göre farklılık gösteren hizmetler olduğu da bilinmektedir. Ancak bir havalimanında genel manada; temel havalimanı hizmetleri, ticari faaliyetler ve yer hizmeti olarak sinıflandırılan üç hizmet grubunda hizmet sunulduğu kaydedilmektedir. $\mathrm{Bu}$ durum ise hizmetin sunulduğu havalimanının büyüklüğü, havalimanında tercih edilen işletim modeli ve yürütülen ticari faaliyetlerdeki çeşitliliğe göre farklılık gösterebilmektedir. Havalimanlarında genel manada yürütülen hizmetleri çizelge $2.1^{\prime}$ de olduğu gibi ifade etmemiz mümkündür (Şengür, 2017: 755).

Çizelge 2.1. Havaalanlarında sunulan hizmetler - yürütülen faaliyetler (Kuyucak,2007)

\begin{tabular}{|c|c|c|}
\hline Operasyonel & Yer Hizmetleri & Ticari \\
\hline $\begin{array}{ll}\text { - } & \text { Hava trafik kontrol } \\
\text { - } & \text { Meteoroloji } \\
\text { - } & \text { Haberleşme ve uçuş bilgi } \\
& \text { sistemleri } \\
\text { - } & \text { Polis ve güvenlik }\end{array}$ & $\begin{array}{ll}\text { - } & \text { Temsil } \\
\text { - } & \text { Yolcu trafik } \\
\text { - } & \text { Yük kontrolü ve } \\
& \text { haberleşme Ramp: Ramp, } \\
& \text { kargo ve posta, uçak }\end{array}$ & $\begin{array}{ll}\text { - } & \text { Vergisiz mağazalar } \\
\text { - } & \text { Diğer mağazalar } \\
\text { - } & \text { Restoran ve kafeler } \\
\text { - } & \text { Eğlence hizmetleri } \\
\text { - } & \text { Oteller }\end{array}$ \\
\hline
\end{tabular}




\begin{tabular}{|c|c|c|}
\hline $\begin{array}{l}\text { - İtfaiye, ambulans ve } \\
\text { ilkyardım hizmetleri } \\
\text { - } \quad \text { Pist, apron ve taksi yolu } \\
\text { bakımı } \\
\text { - } \quad \text { Diğer faaliyetler }\end{array}$ & $\begin{array}{ll} & \text { temizlik, birim yükleme } \\
\text { - } & \text { gereçlerinin kontrolü } \\
& \text { Uçă hat bakım, yakıt ve } \\
\text { - } & \text { Uçuş operasyon } \\
\text { - } & \text { Ulaşım } \\
\text { - } & \text { İkram servis } \\
\text { - } & \text { Gözetim ve yönetim } \\
\text { - } & \text { Uçak özel güvenlik hizmet } \\
& \text { ve denetimi }\end{array}$ & $\begin{array}{ll}\text { - } & \text { Bankalar } \\
\text { - } & \text { Araç kiralama ve park } \\
\text { - } & \text { hizmetleri } \\
& \text { Toplantı ve iletişim } \\
\text { kolaylıkları } \\
\text { - } & \text { Kuaför, kuru temizleme } \\
& \text { vb. kişisel hizmetler } \\
\text { - } & \text { Reklam etkinlikleri } \\
\text { - } & \text { Sağlık hizmetleri } \\
\text { - } & \text { Diğer faaliyetler }\end{array}$ \\
\hline Havacılık hizmetleri & & Havacılık dışı hizmetler \\
\hline
\end{tabular}

Havaalanlarında sunulan hizmetler birbirinden farklı olarak ifade edilse de genel manada hava ulaşım araçlarının işletilmesi ile ilgili operasyonel faaliyetler ve temel hizmetler olarak iki şekilde adlandırılmaktadır. Bununla birlikte, yürütülen bu hizmetlerin temel amacı ulaşım faaliyetlerinin emniyetli bir şekilde devam etmesi olarak ifade edilmektedir. Yer hizmeti olarak adlandırılan hizmet türü direkt olarak uçağa ya da yolcu veya kargoya sunulan hizmetlerdir. Yolcular ve havalimanını kullanan diğer kişiler için ihtiyaç duyulan hususların karşılanması amacıyla sunulan hizmetler ise ticari faaliyetler grubuna giren hizmetlerdir. $\mathrm{Bu}$ faaliyetler içinde yer hizmetleri ve operasyonel hizmetler havacılık hizmetleri içinde, ticari faaliyetler ise havacılık dışı hizmetler içinde değerlendirmektedir (Şengür, 2017: 756).

\subsection{Havaalanı işletmeciliği}

Havaalanlarında genel olarak hava ulaşımının daha sağlıklı ve gerektiği gibi işlemesi konusundaki faaliyetler ağır basıyor olsa da bu alanların özünde birer işletme olduğu unutulmamalıdır. Bu bağlamda havaalanlarında yürütülen faaliyetler başlı başına bir işletmecilik faaliyeti olarak değerlendirilmektedir. Bu doğrultuda havaalanlarının karmaşık veya kompleks olarak nitelendirilebilecek yapısının havaalanlarının işletilmesi konusuna da yansıdığını görmek mümkündür. Havaalanlarının işletilmesi noktasında Dünyada ve Türkiye'de benzer durumlar yaşansa da ulusal anlamda yaşanan birtakım özel durumların varlığından da söz etmek mümkündür.

\subsection{Havaalanı işletmeciliğinde hizmet kalitesinin sağlanması}

Hizmet kalitesi kavramı adından da anlaşılacağı gibi herhangi bir işletme veya yapı altında sunulan hizmetlerin belirli standartlara göre olması veya standartların üstünde olması durumunu ifade etmektedir. Bu anlamda hizmet kalitesinin herhangi bir işletmenin aynı alanda faaliyet gösteren diğer işletmelerden farklı olmasını sağlayan ve bu sayede de rekabet gücünü arttıran önemli bir yönünün olduğunu söylemek mümkündür. Hizmette kalitenin sağlanabilmesi ve sağlanan kalitenin devam ettirilebilmesi için hizmetin sunulmasından önce, hizmetin sunulduğu süre zarfında ve devamında pazar araştırmalarının sürekli olarak yapılması ve hizmeti alan müşterilerin yakın şekilde gözlenerek müşteri beklenti ve ihtiyaçlarının anlaşılmaya çalışılması önemli bir husustur. Buna ek olarak yapılan gözlemler doğrultusunda sunulan hizmetlerde iyileştirmeye gidilmesi de kalitenin sürekliliğini sağlayacaktır (Tavmergen, 2002, s. 31 - 36).

Herhangi bir yapı altında sunulan hizmetlerin kalitesinin sağlanması noktasında farklı birtakım uygulamalara gidilmesi gerektiğini söylemek mümkündür. Diğger bir ifadeyle her 
yapının sunduğu hizmet ve bu hizmetin kalitesinin sağlanması konusunda farklı uygulamalar vardır. Ancak temelde hizmet kalitesinde müşterilerin beklenti ve ihtiyaçlarının karşılanması ana noktasının olduğunu söylemek mümkündür. Bu bağlamda havayolu işletmeciliği açısından hizmetin sağlanması ve kalite noktasında hem sunulan hizmetlerin beklentilere uygun olması hem de bağlantıda olunan kurum ve kuruluşlar arasındaki koordinasyonun sağlanmasının hizmet kalitesine önemli bir katkı sağladığını belirtmek gerekmektedir. Nitekim havayolları işletmelerinin yolculara sunmuş olduğu hizmetin kalitesi açısından uçuş öncesi hizmetler, uçuş esnasında hizmetler ve uçuş sonrasındaki hizmetlerin büyük etkisi olduğu üzerinde durulmaktadır. Ayrıca yine sunulan hizmetin yolcular tarafından algılanma şeklinin havayolu işletmesinin tercih edilmesi veya yolcular ile yaşanan ilişkilere yansıması söz konusu olmaktadır. Bu nedenle de havayolu işletmeleri tarafından sunulan hizmetlerin şayet farklı kurum veya kuruluşlardan alınması söz konusu ise havayolu işletmelerinin bu hizmetlerin kendi hizmet standartlarına uygunluğu noktasında bir denetleme yapması gerektiği ifade edilmektedir. $\mathrm{Bu}$ da havayolu işletmelerinin birlikte çalıştığı kurum ve kuruluşlar ile yakın bir koordinasyonu gerekli kilmaktadır (TOBB, 2014: 92).

\subsection{Havaalanı işletmeciliğinde yolcu memnuniyeti}

Özellikle son dönemlerde havayolu işletmeciliğini yaygınlaşması ve bu nedenle bu alanda yaşanan rekabet ortamı, havayolu işletmeleri açısından yolcuların beklenti ve isteklerine daha fazla yönelim olmasını, diğer bir ifade ile yolcu memnuniyetinin üst düzeyde sağlanması gerekliliğini ortaya çıkarmıştır. Yine yaşanan rekabet ortamı ve sunulan hizmetler yolcu beklentilerinin de üst düzeye çıkması gibi bir sonuç doğurmuştur. Havayolu işletmeleri, yaşanan rekabet ortamında başarılı olabilmek için müşterilerin değişen ihtiyaç ve taleplerini iyi anlamak ve karşılamak gibi bir misyon üstlenmişlerdir. Nitekim havayolu işletmelerinin artan sayısı ile birlikte bu işletmeler belirli bir müşteri profili yakalamakla birlikte mevcut müşterilerini kaybetmeden yeni müşteriler kazanma yoluna gitmektedirler. $\mathrm{Bu}$ da temelde müşteri memnuniyetinin sağlanması ve buna yönelik pazarlama stratejilerinin uygulanması zorunluluğunu doğurmuştur (Okumuş \& Asil, 2007: 170).

\subsubsection{Müşteri memnuniyetinin ölçülmesi}

Müşteri memnuniyeti genel olarak değerlendirildiğinde müşterilerin bir işletmeden sürekli olarak alışveriş davranışında bulunmaları kapsamında ele alınan bir yapı olduğu görülmektedir. Bu doğrultuda bahsedilen davranışın müşteri memnuniyetinin en bariz göstergesi olduğunu söylemek mümkündür. Ancak literatürde bu konunun farklı ve detaylı birtakım ölçümlerle ele alınabileceğinden bahsedilmektedir. Bununla birlikte yapılacak olan farklı ölçümler müşteri memnuniyetine dair daha net sonuçlar verebilmekte ve işletmeler açısından geleceğe dair planlamalarda daha kullanışlı veriler sağlamaktadır. Nitekim yapılacak olan ölçümler açısından işletmelerin kendilerini test edebilmelerini sağlayacak parametrelere de yer verilmektedir. Bu noktada öncelikli olarak müşteri memnuniyetinin ölçümünün gerekli görülmesini sağlayan unsurları incelediğimizde bunların;

- $\quad$ işletmeler tarafından müşterilerin beklenti ve ihtiyaçlarının müşteri yaklaşımları üzerinden değerlendirilmesini sağlaması, 
- müşterilerin mevcut beklenti ve ihtiyaçlarının işletmeler tarafından nasıl karşılanabildiğinin tespit edilmesi,

- $\quad$ yapılacak olan değerlendirme sonucunda elde edilen verilere göre işletmenin hizmet ve faaliyetlerinin geliştirilmesi,

- $\quad$ elde edilen veriler ışığında işletmenin hedef ve stratejilerine yön verilmesi

şeklinde sıralandığı görülmektedir (Burucuoğlu, 2011: 20).

Müşteri memnuniyetinin ölçümü olarak değerlendirilen uygulamada müşterilerin memnuniyetinin ölçüldüğü düşünülse de esas itibariyle işletmeler müşterilerin bakış açılarına göre kendilerini değerlendirmektedirler. $\mathrm{Bu}$ ölçümün yapılmasının temel sebeplerinden biri işletmelerin müşteri gözünden gördükleri yansımalarına yine müşteri odaklı olarak şekil vermelerinin sağlamasıdır. Bu nedenle yapılacak olan ölçümler işletmeler için bir sonraki adımda neler yapılacağına ışık tutmaktadır. Yapılacak olan değişimlerde herhangi bir şekilde gerekliliğin gerisinde kalmamak adına işletmelerin müşteri memnuniyeti ölçümlerini sık sık yapmaları ve dönütlere göre kendilerine şekil vermeleri gerekmektedir. Literatürde müşteri memnuniyeti ile ilgili ölçüm teknikleri özetle aşağıdaki gibi sıralanmaktadır.

- Müş̧teri memnuniyetinin ölçümlenmesinde kullanılacak yöntemlerden biri, daha çok konuya hâkim olan kişilerin katılımı ile gerçekleştirilen ve danışma paneli olarak adlandırılan yöntemdir. Bu yöntemde müşterilerle memnuniyet konusunda görüşmeler yapılarak işletmelerin geleceğe dair planları belirlenmektedir (Odabaşı, 2003: 155).

- $\quad$ Müşteri memnuniyetinin belirlenmesi ile ilgili genel olarak kullanılan yöntem ise anket yöntemi olarak bilinmektedir. Bu yöntem tüketicilere yöneltilen çeşitli sorulara verilen cevaplar doğrultusunda işletmelerin faaliyetlerine yön vermesini içermektedir (Seyidoğlu, 2009: 39).

- $\quad$ Profesyonel bir kişi ya da belirli bir ekip tarafından gerçekleştirilen ve belirli bir grup üzerine odaklanılarak yapılan memnuniyet ölçümü yöntemi ise odak grupları olarak adlandırılmaktadır. Bu yöntemde genel bir müşteri kitlesinin değil yalnızca odaklanılan grubun memnuniyet durumuna durumu ölçümleme yapılır (Odabaşı, 2003: 152).

- $\quad$ Bir diğer ölçüm tekniği ise işletmelerin aynı sektörde ya da pazarda yer aldığı farklı işletmeler ile kıyaslanmasına dayanan yöntemdir. Bu yöntemde iki yapının muadil ürünlerine dair memnuniyetler ölçülerek işletme kendine dair çözüm yolları arayışına girer (Koçel, 2007: 313).

Bahsedilen memnuniyet ölçüm tekniklerinden biri ya da birden fazlası ile elde edilecek olan sonuçlara yönelik olarak yapılacak iyileştirmeler işletmelerin hem müşteri memnuniyeti açısından üst sıralara çıkması hem de varlığını sürdürmesini sağlaması bakımından büyük bir öneme sahiptir. 
3. Havaalanlarında müşteri memnuniyetinin sağlanması: Van Ferit Melen havaalanı örneği

\subsection{Araştırmanın amacı}

Yapılan çalışmada temel amaç, havayolu yolcu taşımacılığı alanında müşteri memnuniyeti ya da memnuniyetsizliğine neden olan unsurların tespit edilmesi, mevcut havayolu taşımacılığını kullanan müşterilerin elde tutulması ve bunlara ek olarak havayolu taşımacılığına yeni müşterilerin kazandırılması olarak ifade edilebilir. Bu bağlamda hava taşımacılığında Van Ferit Melen Havalimanı'nı kullanan müşteriler üzerinde araştırmalar yapılıp memnuniyet durumları ile memnuniyetsizlikleri incelenmiş ve bunların sebepleri tespit edilmeye çalışılmıştır.

Ayrıca çalışmamızda havayolu müşterilerinin memnuniyet durumları ve bu durumlar üzerinde etkili olan faktörler müşteri gözünden ele alınarak havayolu yolcu taşımacılığındaki memnuniyet unsurlarının geliştirilmesi ve memnuniyetsizliğe sebep olan unsurların ortadan kaldırılması da bir diğer amaç olarak ifade edilebilir.

\subsection{Araştırmanın önemi}

Hazırlanan çalışma havayolu yolcu taşımacılı̆̆ında müşterilerin memnuniyeti, durumlarını ya da memnuniyetsizliklerini etkileyen hususların tespit edilmesi ve bu tespit edilen hususların literatüre kazandırılarak işletmeler tarafından değerlendirmeye alınıp sektörün daha iyi bir hale getirilmesini sağlaması açısından önem arz etmektedir.

\subsection{Araştırmanın sınırları}

Yapılan araştırma havayolu taşımacılığında 03.11.2020-08.11.2020 tarihleri arasında Van Ferit Melen Havaalanı'nı kullanan 300 sayıda yolcudan, Özkoç (2018) tarafından geliştirilen anket araştırmasına, katılım konusunda gönüllü olan kişilerle sınırlıdır. Bu bağlamda araştırmanın belirtilen tarihlerde ilgili havalimanını kullanan bütün yolcuları kapsamaması çalışmanın ilk sinırlılığı olarak değerlendirilebilir.

Çalışma belirli bir zaman aralığında uygulandığı için, araştırmaya katılan yolcuların bu zaman aralığındaki memnuniyetsizliklerini yansıtmaktadır. Bu bağlamda yolcu taşımacılığının daha yoğun olduğu özel zaman dilimlerine dair memnuniyet ya da memnuniyetsizlik hususları çalışmaya aktarılamamıştır.

İçinde bulunulan pandemi dönemi nedeniyle havaalanlarındaki yolcu taşıma faaliyetlerinin daha seyrek hale getirilmesi ise çalışmanın bir diğer kısıtlılığını oluşturmaktadır.

Çalışmadan elde edilen veriler ankete katılan bireylerin kişisel beyanlarıdır. Bu nedenle verilerin öznel yapıda olması kaçınılmazdır. Bu durum tüm çalışmalarda olduğu gibi bu çalışmada da yanlı cevaplar verilebilmesi problemini doğurmaktadır.

\subsection{Araştırmanın yöntemi}

Araştırmamız, felsefi anlamda temel, çalışmada güdülen amaç açısından açıklayıcı, kullanılan yöntem bakımından nicel ve analiz açısından birey düzeyinde bir çalışmadır.

Nicel araştırmalarda ise çalışmaya bünyesindeki olaylar ve olgular dıştan ölçülerek bunlarda var olan neden - sonuç ilişkisi içinde gerçeklere ulaşmak hedeflenmektedir. Nicel araştırmalarda daha çok sayısal veriler kullanıldığı için ulaşılmak istenen sonuçlar, kesin ve 
genel - geçer sonuçlardır. Nicel araştırmalarda genelde anket yöntemi kullanılmaktadır (İslamoğlu \& Alnıaçık, 2014: 45; Altunışık vd. 2012: 64 - 71). Araştırmanın analizinde kullanılacak verilerin toplanması için anket yöntemi kullanılmıştır.

\subsection{Araştırmanın modeli}

Hazırlanan araştırma "Van Ferit Melen Havaalanı'nda sunulan hizmetler noktasında müşteri memnuniyetinin seviyesi nedir?", "Müşteri memnuniyetsizliğinin nedenleri nelerdir?" soruları çerçevesinde modellenmiştir. Bu bağlamda havaalanlarında sunulan hizmetlerden faydalanan müşterilerin memnuniyet düzeylerini etkileyen faktörlerin farklılaşıp farklılaşmadığını belirleyebilmek için 4 hipotez oluşturulmuştur. Araştırmanın hipotezleri aşağıda yer almaktadır.

H1a: Havaalanlarında müşteri memnuniyetini etkileyen faktörler müşterilerin eğitim durumuna göre anlamlı farklılık göstermektedir.

H1b: Havaalanlarında müşteri memnuniyetini etkileyen faktörler müşterilerin cinsiyetine göre anlamlı farklılık göstermektedir.

H1c: Havaalanlarında müşteri memnuniyetini etkileyen faktörler müşterilerin gelir durumuna göre farklılık göstermektedir.

H1d: Havaalanlarında müşteri memnuniyetini etkileyen faktörler müşterilerin mesleğine göre anlamlı farklılık göstermektedir.

\subsection{Evren ve örneklem}

Yapılan araştırmanın evrenini; Van Ferit Melen Havaalanı'nı 03.11.2020-08.11.2020 tarihleri aralığında kullanan havayolu yolcuları oluşturmaktadır. Belirlenen tarih aralığında ilgili havaalanı toplam 6000 yolcu tarafından kullanılmış ve bunlardan 300 tanesi çalışmamıza katılmıştır. Katılan yolcu sayısı belirtilen tarihlerde havaalanını kullanan toplam yolcu sayısından oluşan araştırmanın evreninden, evren örneklem oranı dikkate alınarak tespit edilmiştir.

\subsection{Bulgular ve yorum}

\subsubsection{Tanımlayıcı istatistikler}

Araştırmaya katılan bireylerin demografik özelliklerinden biri olan yaş değişkeni sürekli bir değişkendir. Yaş değişkenine ait tanımlayıcı istatistikler Çizelge 3.1'de verilmektedir.

Çizelge 3.1. Yaş değişkenine ait tanımlayıcı istatistikler

\begin{tabular}{cccccc}
\hline Değişken & Gözlem Sayısı & Ortalama & Standart Sapma & $\begin{array}{c}\text { Minimum } \\
\text { Değer }\end{array}$ & $\begin{array}{c}\text { Maksimum } \\
\text { Değer }\end{array}$ \\
\hline Yaş & 300 & 33,58 & 11,0228 & 17 & 71 \\
\hline
\end{tabular}

Çizelge 3.1 incelendiğinde ankete katılanların 300 kişi olduğu sonucuna ulaşılmıştır. Bu bireylerin 17 ile 71 yaş aralığında olduğu tespit edilmiştir. Yaş değişkeninin ortalaması 33,58, standart sapması ise 11,0228 olarak hesaplanmıştır.

Çizelge 3.2. Kategorik değişkenlere ait frekans tablosu

\begin{tabular}{cccc}
\hline Değişken & Kategoriler & Frekans & Yüzde \\
\hline Cinsiyet & 1: Erkek & 158 & $\% 52,7$
\end{tabular}




\begin{tabular}{|c|c|c|c|}
\hline & 2: Kadın & 142 & $\% 47,3$ \\
\hline \multirow{4}{*}{ Gelir Durumu } & 1: 1000-1999 & 57 & $\% 19$ \\
\hline & 2: 2000-2999 & 133 & $\% 44,3$ \\
\hline & 3: 3000-3999 & 75 & $\% 25$ \\
\hline & 4: 4000 ve yukarısı & 35 & $\% 11,7$ \\
\hline \multirow{6}{*}{ Meslek } & 1: Ücretli çalışan & 158 & $\% 52,7$ \\
\hline & 2: İşyeri sahibi & 37 & $\% 12,3$ \\
\hline & 3: Emekli & 16 & $\% 5,3$ \\
\hline & 4: Öğrenci & 21 & $\% 7$ \\
\hline & 5: İşsiz & 17 & $\% 5,7$ \\
\hline & 6: Diğer & 51 & $\% 17$ \\
\hline \multirow{5}{*}{ Eğitim Durumu } & 1: İlkokul & 10 & $\% 3,3$ \\
\hline & 2: Ortaokul & 50 & $\% 16,7$ \\
\hline & 3: Lise & 112 & $\% 37,3$ \\
\hline & 4: Üniversite & 128 & $\% 42,7$ \\
\hline & 5: Yüksek Lisans & 0 & $\% 0$ \\
\hline \multirow[t]{2}{*}{ Ulaşım Tercihi: Tren } & 1: Evet & 53 & $\% 17,7$ \\
\hline & 2: Hayır & 247 & $\% 82,3$ \\
\hline \multirow{2}{*}{ Ulaşım Tercihi: Hava } & 1: Evet & 244 & $\% 81,3$ \\
\hline & 2: Hayır & 56 & $\% 18,7$ \\
\hline \multirow{2}{*}{ Ulaşım Tercihi: Kara } & 1: Evet & 127 & $\% 42,3$ \\
\hline & 2: Hayır & 173 & $\% 57,7$ \\
\hline \multirow{2}{*}{ Ulaşım Tercihi: Deniz } & 1: Evet & 13 & $\% 4,3$ \\
\hline & 2: Hayır & 287 & $\% 95,7$ \\
\hline \multirow{4}{*}{ Seyahat Sıklığı } & 1: Yilda $1 \mathrm{kez}$ & 120 & $\% 40$ \\
\hline & 2: Ayda $1 \mathrm{kez}$ & 73 & $\% 24,3$ \\
\hline & 3: Ayda 2-3 kez & 97 & $\% 32,4$ \\
\hline & 4: Her gün & 10 & $\% 3,3$ \\
\hline \multirow{4}{*}{ Seyahat Sayısı } & 1: Yilda $1 \mathrm{kez}$ & 187 & $\% 62,3$ \\
\hline & 2: Ayda 1 kez & 69 & $\% 23$ \\
\hline & 3: Ayda 2-3 kez & 44 & $\% 14,7$ \\
\hline & 4: Haftada 1 & 0 & $\% 0$ \\
\hline
\end{tabular}

Çizelge 3.2 incelendiğinde ankete katılan bireylerin $\% 52,7^{\prime}$ si erkek ve $\% 47,3^{\prime}$ ünü kadındır. Ankete katılan bireylerin \%44,3'ünün gelir durumu aylık 2000-2999 TL, \%25'inin gelir durumu aylık 3000-3999 TL, \%19'unun gelir durumu aylık 1000-1999 TL ve \%11,7'sinin gelir durumu aylık 4000 TL ve üstünde olduğu tespit edilmiştir. Ankete katılan bireylerin \%52,7'si ücretli çalışan olduklarını belirtirken $\% 5,7^{\prime}$ si işsiz olduklarını belirtmektedir. Ankete katılan bireylere eğitim durumları sorulduğunda $\% 42,7^{\prime} \operatorname{sinin}$ üniversite mezunu, \%37,3'ünün lise mezunu, \%16,7'sinin ortaokul mezunu ve \%3,3'ünün ise ilkokul mezunu olduğu sonucuna ulaşılmıştır. Ankete katılan bireylerin \%17,7'sinin ulaşım için tren yolunu tercih ettikleri $\% 82,3$ 'ünün ise diğer ulaşım yollarını tercih ettikleri tespit edilmiştir. Ulaşım yolu tercihi olarak ankete katılan bireylerin \%81,3'ü hava yolunu tercih ederken \%18,7'si farklı bir ulaşım yolunu tercih ettiğini belirtmektedir. Ankete katılan bireylerin $\% 42,3$ ü kara yolunu tercih ederken \%57,7'si kara yolunu tercih etmediklerini belirtmiştir. Deniz yolunu tercih eden bireyler ankete katılan bireylerin \%4,3'ünü oluşturmaktadır. Ankete katılan bireylere "Seyahat sıklığınız nedir?" sorusu yöneltildiğinde bireylerin \%40'ının yılda 1 kez, \%24,3'ünün ayda $1 \mathrm{kez}$ \%32,4'ünün ayda 2-3 kez ve \%3,3'ünün her gün seyahat ettikleri sonucuna ulaşılmıştır. Ankete katılan bireylere "Van Ferit Melen Havalimanı'ndan kaç kere seyahat ettiniz?" sorusu yöneltildiğinde bireylerin \%62,3’ü yılda 1 kez, \%23'ü ayda 1 kez ve $\% 14,7^{\prime}$ si ayda 2-3 kez olduğunu belirtmiştir. 


\subsubsection{Güvenilirlik ve iç tutarlılık analizi sonuçları}

Anketin ikinci bölümünde yer alan 5'li Likert ölçekli 19 soru için güvenilirlik analizi yapılmış ve sonuçlar Çizelge 3.3'te verilmektedir.

Çizelge 3.3. Güvenilirlik analizi sonuçları

\begin{tabular}{ccc}
\hline Anket Ölçeği & Cronbach's Alpha Katsayısı & Madde Sayısı \\
\hline 5'li Likert Ölçekli Sorular & 0,896 & 19 \\
\hline
\end{tabular}

Likert ölçekli sorular için Cronbach's Alpha katsayısı 0,896 olarak hesaplanmıştır. 0,896 değeri ankette kullanılan ölçeğin oldukça yüksek derecede güvenilir olduğunu göstermektedir. Anketteki likert ölçekli sorular 4 bölüme ayrılmıştır. Bu nedenle bu 4 bölüm için iç tutarlılık analizi yapılmış ve sonuçlar Çizelge 3.4'te verilmektedir.

Çizelge 3.4. İç tutarlılık analizi sonuçları

\begin{tabular}{lll}
\hline Ölçekler & $\begin{array}{l}\text { Cronbach's Alpha } \\
\text { Katsayısı }\end{array}$ & \multirow{2}{*}{ Madde Sayısı } \\
\hline 1. Ölçek (Ankette 9. sorunun alt maddelerini kapsar.) & 0,844 & 4 \\
2. Ölçek (Ankette 10. sorunun alt maddelerini kapsar.) & 0,848 & 5 \\
3. Ölçek (Ankette 11. Sorunun alt maddelerini kapsar.) & 0,863 & 7 \\
4. Ölçek (Ankette 12. Sorunun altı maddelerini kapsar.) & 0,820 & 3 \\
\hline
\end{tabular}

Çizelge 3.4 incelendiğinde 1. ölçeğin Cronbach's Alpha katsayısı 0,844 olarak hesaplanmıştır. 1. ölçek 4 sorudan oluşmaktadır. Bu sonuçlar altında 1. ölçeğin iç tutarlılığının yüksek olduğu görülmektedir. 2. ölçeğin 5 sorudan oluştuğu ve Cronbach's Alpha katsayısı 0,848 olduğu sonucuna ulaşılmıştır. 2. ölçeğin iç tutarlılığı oldukça yüksektir. 3. ölçeğin 7 sorudan oluştuğu ve Cronbach's Alpha katsayısının 0,863 olduğu sonucuna ulaşılmıştır. 3. ölçeğin iç tutarlılığının oldukça yüksek olduğu tespit edilmiştir. 4. ölçeğin ise 3 sorudan oluştuğu ve Cronbach's Alpha katsayısının 0,820 olduğu tespit edilmiştir. 4. ölçeğin de iç tutarlılığının yüksek olduğu sonucuna ulaşılmıştır. Tüm bu sonuçlar altında anketin güvenilir ve tutarlı olduğu sonucuna ulaşılmıştır.

\subsubsection{Normallik testi sonuçlan (Kolmogorov-Smirnov)}

Çalışmada kullanılan değişkenlerin normal dağılım gösterip göstermedikleri KolmogorovSmirnov normallik testi ile sınanmış analizde kullanılacak olan tüm değişkenlerin normal göstermediği sonucuna ulaşılmıştır. Bu bağlamda çalışmada parametrik olmayan hipotez testleri kullanılacaktır.

\subsubsection{Faktör analizi}

Araştırmada kullanılan örgütsel adalet ölçeği ve boyutları ile örgütsel sessizlik ve boyutlarının Öncelikle veri setinin faktör analizi için uygun olup olmadığı KMO (KaiserMeyer-Olkin) testi ve Bartlett testi ile sınanmıştır. Sıfır hipotezi veri setinin faktör analizine uygun olmadığ şseklinde kurulmaktadır. KMO testi ve Bartlett testine ilişkin sonuçlar Çizelge 3.5' de gösterilmektedir.

Çizelge 3.5. KMO ve Bartlett testi sonuçları

\begin{tabular}{ll}
\hline Test Adı & Test İstatistiği \\
\hline KMO (Kaiser-Meyer-Olkin) & 0,837 \\
Bartlett testi & 3229,147 \\
& $(0,000)^{* * *}$ \\
\hline
\end{tabular}


KMO testi sonucuna göre $0,837>0.50$ olduğu için veri seti faktör analizi için uygundur. Bartlett testi sonucu incelendiğinde ise olasılık değeri $p<0,01$ olduğu için sıfır hipotezi reddedilmektedir. Bu durumda veri setinin faktör analizi için uygun olduğu tespit edilmiştir.

Faktör analizi için 19 sorudan oluşan 19x19'luk bir korelasyon matrisi oluşturulmuş ve faktör analizi uygulanmıştır. Faktör analizi ile Van Ferit Melen Havaalanı'nı tercih eden bireylerin memnuniyet düzeylerinin hangi değişkenler tarafından etkilendiğinin belirlenmesi amaçlanmıştır. Faktör analizi uygulanan her bir değişken için oransal değişmeler Çizelge 3.6' da verilmektedir.

Çizelge 3.6. Değişim oranları

\begin{tabular}{|c|c|c|}
\hline Değişken & İlk Öz Değer & $\begin{array}{l}\text { İndirgenmiş } \\
\text { Değer }\end{array}$ \\
\hline 1. Van Ferit Melen Havalimanı'na ulaşım kolaydır. & 1,000 & 0,709 \\
\hline 2. Van Ferit Melen Havalimanı'nın büyüklüğ̈̈ yeterlidir. & 1,000 & 0,773 \\
\hline $\begin{array}{l}\text { 3. Van Ferit Melen Havalimanının araç park yerleri ve yolcu indirme } \\
\text { yerleri yeterlidir. }\end{array}$ & 1,000 & 0,714 \\
\hline $\begin{array}{l}\text { 4. Van Ferit Melen Havalimanı'ndan uçak ile seyahat, tren ve otobüs } \\
\text { yolculuğuna alternatif olarak düşünülebilir. }\end{array}$ & 1,000 & 0,596 \\
\hline 5. Van Ferit Melen Havalimanında kafeterya ve restoran sayısı yeterlidir. & 1,000 & 0,608 \\
\hline $\begin{array}{l}\text { 6. Van Ferit Melen Havalimanında her zaman taze yiyecek ve içecek } \\
\text { bulabilirim }\end{array}$ & 1,000 & 0,730 \\
\hline 7. Van Ferit Melen Havalimanında oturma yerleri yeterlidir & 1,000 & 0,775 \\
\hline 8. Van Ferit Melen Havalimanında oturma yerleri geniş ve rahattır. & 1,000 & 0,658 \\
\hline 9. Van Ferit Melen Havalimanında kitap ve gazete servisleri yeterlidir. & 1,000 & 0,465 \\
\hline 10. Van Ferit Melen Havalimanında diğer şehirlere uçuş programı sıktır & 1,000 & 0,670 \\
\hline 11. Van Ferit Melen Havalimanında uçaklar zamanında kalkmaktadır. & 1,000 & 0,836 \\
\hline 12. Van Ferit Melen Havalimanında check-in bekleme süreleri normaldir. & 1,000 & 0,828 \\
\hline 13. Van Ferit Melen Havalimanında bagaj teslimi çabuk ve yeterlidir. & 1,000 & 0,778 \\
\hline 14. Van Ferit Melen Havalimanında bagaj alımı hızlı ve rahattır. & 1,000 & 0,765 \\
\hline $\begin{array}{l}\text { 15. Van Ferit Melen Havalimanında uçak bileti satın alabileceğim yerler } \\
\text { yeterlidir. }\end{array}$ & 1,000 & 0,754 \\
\hline 16. Van Ferit Melen Havalimanında gümrük işleri hızlı ve sorunsuzdur & 1,000 & 0,562 \\
\hline 17. Van Ferit Melen Havalimanında çalışanlar samimi ve saygılıdır. & 1,000 & 0,713 \\
\hline $\begin{array}{l}\text { 18. Van Ferit Melen Havalimanında çalışanlar yolcuların sorduğu } \\
\text { sorulara karşı bilgilidir. }\end{array}$ & 1,000 & 0,780 \\
\hline $\begin{array}{l}\text { 19. Van Ferit Melen Havalimanında personel sorun çözümünde } \\
\text { samimidir. }\end{array}$ & 1,000 & 0,697 \\
\hline
\end{tabular}

Çizelge 3.6 incelendiğinde her değişken için başlangıç değerleri 1 olarak kabul edilmektedir. Faktör analizi ile boyut indirgendikten sonra her bir değişken için bilgi miktarı "İndirgenmiş Değer" sütununda verilmektedir. Başlangıçta bilgi düzeyi 1 olan "Van Ferit Melen Havalimanı'na ulaşım kolaydır" değişkeninin faktör analizi ile boyut indirgendikten sonra bilgi düzeyi 0,709 olmuştur. Bu değişkenin 0,291 bilgi kaybına uğradığı sonucuna ulaşılmıştır. Bilgi kaybının 0,50'nin üzerinde yani indirgenmiş değeri 0,50'nin altında olan değişkenler analizden çıkarılmalıdır (Mert, 2016). Çizelge 3.7 incelendiğinde indirgenmiş değeri 0,50' nin altında olan değişken bulunmamaktadır. İndirgenmiş değeri 0,836 ile en yüksek olan değişken "Van Ferit Melen Havalimanında uçaklar zamanında kalkmaktadır." değişkenidir. Bu değişken ile varyansın \%83,6'sı ortaktır. Faktör analizinde yer alan bir diğer sonuç çıktısı varyans açıklama oranlarıdır. Varyans açıklama oranları Çizelge 3.7'de gösterilmektedir. 
Çizelge 3.7. Faktör analizi ile açıklanan toplam varyans

\begin{tabular}{|c|c|c|c|c|c|c|c|c|c|}
\hline \multirow[b]{2}{*}{ 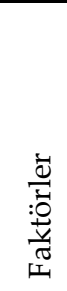 } & \multicolumn{3}{|c|}{ Başlangıç Öz Değerleri } & \multicolumn{3}{|c|}{$\begin{array}{c}\text { Türetilen Kareli Ağırlıklar } \\
\text { Toplamı } \\
\end{array}$} & \multicolumn{3}{|c|}{$\begin{array}{c}\text { Döndürülmüş Kareli Ağırlıklar } \\
\text { Toplamı }\end{array}$} \\
\hline & 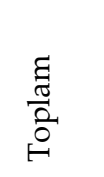 & 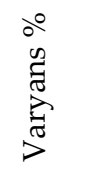 & 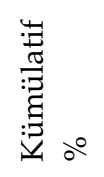 & 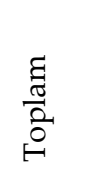 & 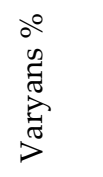 & 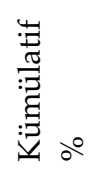 & $\begin{array}{l}\frac{\Xi}{0} \\
\frac{0}{2} \\
\frac{0}{0}\end{array}$ & 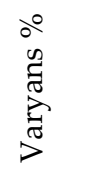 & 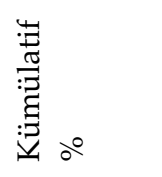 \\
\hline 1 & 6,711 & 35,321 & 35,321 & 6,711 & 35,321 & 35,321 & 3,226 & 17,032 & 17,032 \\
\hline 2 & 2,512 & 13,223 & 48,544 & 2,512 & 13,223 & 48,544 & 2,805 & 14,763 & 31,795 \\
\hline 3 & 1,604 & 8,442 & 56,985 & 1,604 & 8,442 & 56,985 & 2,583 & 13,596 & 45,391 \\
\hline 4 & 1,464 & 7,707 & 64,692 & 1,464 & 7,707 & 64,692 & 2,481 & 13,056 & 58,447 \\
\hline 5 & 1,117 & 5,879 & 70,571 & 1,117 & 5,879 & 70,571 & 2,304 & 12,124 & 70,571 \\
\hline 6 & 0,830 & 4,371 & 74,942 & & & & & & \\
\hline 7 & 0,786 & 4,136 & 79,078 & & & & & & \\
\hline 8 & 0,581 & 3,057 & 82,135 & & & & & & \\
\hline 9 & 0,552 & 2,905 & 85,040 & & & & & & \\
\hline 10 & 0,512 & 2,696 & 87,736 & & & & & & \\
\hline 11 & 0,409 & 2,154 & 89,891 & & & & & & \\
\hline 12 & 0,335 & 1,762 & 91,653 & & & & & & \\
\hline 13 & 0,313 & 1,647 & 93,300 & & & & & & \\
\hline 14 & 0,294 & 1,546 & 94,845 & & & & & & \\
\hline 15 & 0,258 & 1,359 & 96,204 & & & & & & \\
\hline 16 & 0,213 & 1,120 & 97,324 & & & & & & \\
\hline 17 & 0,196 & 1,032 & 98,356 & & & & & & \\
\hline 18 & 0,164 & 0,862 & 99,217 & & & & & & \\
\hline 19 & 0,149 & 0,783 & 100 & & & & & & \\
\hline
\end{tabular}

Çizelge 3.7 incelendiğinde birinci faktörün toplam içinde 6,711 öz değer ile \%35,321 varyansa, ikinci faktörün toplam içinde 2,512 öz değer ile \%13,223 varyansa, üçüncü faktörün toplam içinde 1,604 öz değer ile \%8,442 varyansa, dördüncü faktörün toplam içinde 1,464 öz değer ile \%7,707 varyansa ve son olarak beşinci faktörün toplam içinde 1,117 öz değer ile \%5,879 varyansa sahip olduğu tespit edilmiştir. Özdeğer istatistiği 1'den büyük olan 5 faktör bulunmaktadır. Birinci faktör toplam varyansın \%17,032'sini açılamaktadır. Birinci ve ikinci faktörler birlikte toplam varyansın \%31,795' ini açılamaktadır. Birinci, ikinci ve üçüncü faktörler birlikte toplam varyansın \%45,391'ini açıklamaktadır. Çizelgedeki ilk 4 faktör birlikte toplam varyansın \%58,447'sini açıklamaktadır. Çizelgedeki 5 faktör ise toplam varyansın \%70,571'ini açıklamaktadır. Faktör analizi ile ilgili olarak bir diğer sonuç çıtısı döndürülmüş faktör yükleri sonuçlarıdır. Bu sonuçlar Çizelge 3.8' de verilmektedir.

Çizelge 3.8. Döndürülmüş faktör yükleri

\begin{tabular}{|c|c|c|c|c|c|}
\hline \multirow[t]{2}{*}{ Değişkenler } & \multicolumn{5}{|c|}{ Faktörler } \\
\hline & 1 & 2 & 3 & 4 & 5 \\
\hline 7. Van Ferit Melen Havalimanında oturma yerleri yeterlidir & 0,860 & & & & \\
\hline $\begin{array}{l}\text { 6. Van Ferit Melen Havalimanında her zaman taze yiyecek ve } \\
\text { içecek bulabilirim }\end{array}$ & 0,829 & & & & \\
\hline $\begin{array}{l}\text { 8. Van Ferit Melen Havalimanında oturma yerleri geniş ve } \\
\text { rahattır. }\end{array}$ & 0,752 & & & & \\
\hline $\begin{array}{l}\text { 5. Van Ferit Melen Havalimanında kafeterya ve restoran sayısı } \\
\text { yeterlidir. }\end{array}$ & 0,729 & & & & \\
\hline $\begin{array}{l}\text { 9. Van Ferit Melen Havalimanında kitap ve gazete servisleri } \\
\text { yeterlidir }\end{array}$ & 0,649 & & & & \\
\hline 2. Van Ferit Melen Havalimanı'nın büyüklüğü yeterlidir. & & 0,822 & & & \\
\hline
\end{tabular}


3. Van Ferit Melen Havalimanının araç park yerleri ve yolcu indirme yerleri yeterlidir.

1. Van Ferit Melen Havalimanı'na ulaşım kolaydır.

4. Van Ferit Melen Havalimanı'ndan uçak ile seyahat, tren ve otobüs yolculuğuna alternatif olarak düşünülebilir.

11. Van Ferit Melen Havalimanında uçaklar zamanında kalkmaktadır.

12. Van Ferit Melen Havalimanında check-in bekleme süreleri normaldir.

10. Van Ferit Melen Havalimanında diğer şehirlere uçuş programi siktır.

15. Van Ferit Melen Havalimanında uçak bileti satın alabileceğim yerler yeterlidir.

14. Van Ferit Melen Havalimanında bagaj alımı hızlı ve rahattır.

16. Van Ferit Melen Havalimanında gümrük işleri hızlı ve sorunsuzdur.

13. Van Ferit Melen Havalimanında bagaj teslimi çabuk ve yeterlidir.

18. Van Ferit Melen Havalimanında çalışanlar yolcuların sorduğu sorulara karşı bilgilidir.

17. Van Ferit Melen Havalimanında çalışanlar samimi ve saygilidir.

19. Van Ferit Melen Havalimaninda personel sorun çözümünde samimidir.
0,803

0,730

0,730

0,819

0,787

0,710

0,789

0,775

0,646

0,636

Çizelge 3.8 incelendiğinde birinci faktör 5 değişkeni kapsamaktadır. Bu değişkenler; "Van Ferit Melen Havalimanında oturma yerleri yeterlidir", "Van Ferit Melen Havalimanında her zaman taze yiyecek ve içecek bulabilirim", "Van Ferit Melen Havalimanında oturma yerleri geniş ve rahattır.", "Van Ferit Melen Havalimanında kafeterya ve restoran sayısı yeterlidir." ve "Van Ferit Melen Havalimanında kitap ve gazete servisleri yeterlidir" değişkenleridir. Birinci faktör "Van Ferit Melen Havalimanı'ndaki sosyal alan faktörü" olarak adlandırılabilir. Birinci faktörün varyans açıklama oranı \%17,032'dir. Bu faktörün Cronbach's Alpha değeri ise $0,848^{\prime}$ dir.

İkinci faktör 4 değişkeni kapsamaktadır. Bu değişkenler; “Van Ferit Melen Havalimanı'nın büyüklüğü yeterlidir.", "Van Ferit Melen Havalimanının araç park yerleri ve yolcu indirme yerleri yeterlidir.", "Van Ferit Melen Havalimanı'na ulaşım kolaydır." ve "Van Ferit Melen Havalimanı'ndan uçak ile seyahat, tren ve otobüs yolculuğuna alternatif olarak düşünülebilir." değişkenleridir. İkinci faktör "Van Ferit Melen Havalimanı'nın fiziksel şartlar faktörü" olarak adlandırılabilir. İkinci faktörün varyans açıklama oranı \%14,763'tür. Bu faktörün Cronbach's Alpha değeri ise $0,844^{\prime}$ tür.

Üçüncü faktör 3 değişkenden oluşmaktadır. Bu değişkenler; “Van Ferit Melen Havalimanında uçaklar zamanında kalkmaktadır.", "Van Ferit Melen Havalimanında checkin bekleme süreleri normaldir." ve "Van Ferit Melen Havalimanında diğer şehirlere uçuş programı sıktır." değişkenleridir. Üçüncü faktör "Van Ferit Melen Havalimanı'nda zaman faktörü" olarak adlandırılabilir. Üçüncü faktörün varyans açıklama oranı \%13,596'dır. Bu faktörün Cronbach's Alpha değeri 0,841'dir.

Dördüncü faktör 4 değiş̧kenden oluşmaktadır. Bu değiş̧kenler; "Van Ferit Melen Havalimanında uçak bileti satın alabileceğim yerler yeterlidir.", "Van Ferit Melen 
Havalimanında bagaj alımı hızlı ve rahattır.", "Van Ferit Melen Havalimanında gümrük işleri hızlı ve sorunsuzdur." ve "Van Ferit Melen Havalimanında bagaj teslimi çabuk ve yeterlidir." değişkenleridir. Dördüncü faktör "Van Ferit Melen Havalimanı'nın uçuş işlemleri faktörü" olarak adlandırılabilir. Dördüncü faktörün varyans açklama oranı \%13,056'dir. Cronbach's Alpha değeri 0,821'dir.

Beşinci faktör 3 değişkeni kapsamaktadır. Bu değişkenler; “Van Ferit Melen Havalimanında çalışanlar yolcuların sorduğu sorulara karşı bilgilidir.", "Van Ferit Melen Havalimanında çalışanlar samimi ve saygılıdır." ve "Van Ferit Melen Havalimanında personel sorun çözümünde samimidir." değişkenleridir. Beşinci faktör "Van Ferit Melen Havalimanı'nda personel faktörü" olarak adlandırılabilir. Beşinci faktörün varyans açıklama oranı \%12,124'tür. Bu faktörün Cronbach's Alpha değeri 0,820'dir.

\subsubsection{Kruskall-Wallis testi sonuçları}

Araştırmada kullanılan değişkenlerin normal dağılım gösterip göstermediği KolmogorovSmirnov normallik testi ile sınanmış ve değişkenlerin normal dağılım göstermediği sonucuna ulaşılmıştı. Bu nedenle hipotez testlerinden parametrik olmayan testler tercih edilmiştir. Çalışmada ankete katılan bireylerin faktör analizi ile belirlenen 5 faktör için bireylerin meslek grupları, gelir grupları ve eğitim durumları arasında anlamlı farklılık olup olmadığı Kruskal-Wallis testi ile sınanmıştır. Testin hipotezleri aşağıda yer almaktadır. Kruskal-Wallis testine ait sonuçlar Çizelge 3.9' da gösterilmektedir.

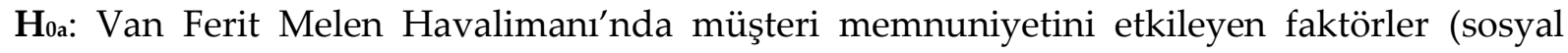
alan, fiziksel şartlar, zaman, uçuş işlemleri, personel) müşterilerin meslek gruplarına göre anlamlı farklılık göstermemektedir.

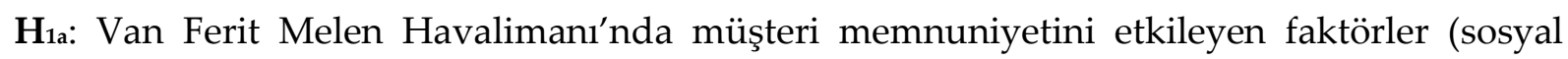
alan, fiziksel şartlar, zaman, uçuş işlemleri, personel)müşterilerin meslek gruplarına göre anlamlı farklılık göstermektedir.

$H_{0 b}$ : Van Ferit Melen Havalimanı'nda müşteri memnuniyetini etkileyen faktörler (sosyal alan, fiziksel şartlar, zaman, uçuş işlemleri, personel)müşterilerin gelir gruplarına göre anlamlı farklılık göstermemektedir.

$H_{1 b}$ : Van Ferit Melen Havalimanı'nda müşteri memnuniyetini etkileyen faktörler (sosyal alan, fiziksel şartlar, zaman, uçuş işlemleri, personel) müşterilerin gelir gruplarına göre anlamlı farklılık göstermektedir.

$\mathbf{H}_{0 \mathrm{c}}$ : Van Ferit Melen Havalimanı'nda müşteri memnuniyetini etkileyen faktörler (sosyal alan, fiziksel şartlar, zaman, uçuş işlemleri, personel) müşterilerin eğitim durumlarına göre anlamlı farklılık göstermemektedir.

Hıc: Van Ferit Melen Havalimanı'nda müşteri memnuniyetini etkileyen faktörler (sosyal alan, fiziksel şartlar, zaman, uçuş işlemleri, personel) müşterilerin eğitim durumlarına göre anlamlı farklılık göstermektedir.

Çizelge 3.9. Kruskal - Wallistesti sonuçları

\begin{tabular}{llll}
\hline Faktörler & Gruplar & Test İstatistiği & Olasılık değeri (p) \\
\hline Faktör 1 & Meslek grupları & 8,292 & 0,141 \\
(Sosyal alan) & Gelir grupları & 4,699 & 0,195
\end{tabular}




\begin{tabular}{llll} 
& Eğitim durumu & 8,752 & $0,033^{* *}$ \\
\hline \multirow{2}{*}{ Faktör 2 } & Meslek grupları & 14,783 & $0,011^{* *}$ \\
(Fiziksel şartlar) & Gelir grupları & 23,506 & $0,000^{* * *}$ \\
& Eğitim durumu & 1,994 & 0,574 \\
\hline \multirow{2}{*}{ Faktör 3 } & Meslek grupları & 3,980 & 0,552 \\
(Zaman) & Gelir grupları & 16,276 & $0,001^{* * *}$ \\
& Eğitim durumu & 2,545 & 0,467 \\
\hline \multirow{2}{*}{ Faktör 4 } & Meslek grupları & 4,962 & 0,420 \\
(Uçuş işlemleri) & Gelir grupları & 5,092 & 0,165 \\
& Eğitim durumu & 0,946 & 0,814 \\
\multirow{2}{*}{ Faktör 5 } & Meslek grupları & 14,477 & $0,013^{* *}$ \\
(Personel) & Gelir grupları & 12,234 & $0,007^{* * *}$ \\
\hline
\end{tabular}

*** \%1 anlamlılık düzeyini göstermektedir

** \%5 anlamlılık düzeyini göstermektedir.

Çizelge 3.9 incelendiğinde Van Ferit Melen Havaalanı'nda müşteri memnuniyetini etkileyen sosyal alan faktörü ile müşterilerin meslek grupları ve gelir grupları arasında anlamlı farklılıklar olmadığı sonucuna ulaşılmıştır ( $\mathrm{p}>0.05)$. Van Ferit Melen Havaalanı'nda sosyal alan faktörü ile müşterilerin eğitim durumları arasında anlamlı farklılıklar olduğu sonucuna ulaşılmıştır $(\mathrm{p}<0,05)$.

Van Ferit Melen Havaalanı'nda müşteri memnuniyetini etkileyen faktörlerden havaalanının fiziksel şartları faktörü, müşterilerin meslek ve gelir gruplarına göre anlamlı farklılıklar gösterdiği sonucuna ulaşılmıştır $(p<0,05)$. Fiziksel şartlar faktörünün müşterilerin eğitim durumlarına göre anlamlı farklılıklar göstermediği sonucuna ulaşılmıştır $(p>0,05)$.

Van Ferit Melen Havaalanı'nda müşteri memnuniyetini etkileyen faktörlerden zaman faktörü müşterilerin meslek grupları ve eğitim durumlarına göre anlamlı bir farklılık göstermemektedir $(p>0,05)$. Van Ferit Melen Havaalanı'nda müşteri memnuniyetini etkileyen faktörlerden zaman faktörü müşterilerin gelir gruplarına göre anlamlı farklılık göstermektedir $(\mathrm{p}<0,05)$.

Van Ferit Melen Havaalanı'nda müşteri memnuniyetini etkileyen faktörlerden uçuş işlemleri faktörü müşterilerin meslek grupları, gelir grupları ve eğitim durumlarına göre anlamlı bir farklılık göstermemektedir ( $p>0,05)$.

Van Ferit Melen Havaalanı'nda müşteri memnuniyetini etkileyen faktörlerden havaalanında çalışan personel faktörü müşterilerin meslek grupları ve gelir gruplarına göre anlamlı bir farklılık göstermektedir $(p<0,05)$. Van Ferit Melen Havaalanı'nda müşteri memnuniyetini etkileyen faktörlerden havaalanında çalışan personel faktörü müşterilerin eğitim durumlarına göre anlamlı farklılık göstermemektedir $(p>0,05)$.

\subsubsection{Mann-Whitney U testi}

Araştırmada kullanılan parametrik olmayan hipotez testlerinden bir diğeri Mann-Whitney U testidir. Van Ferit Melen Havaalanını kullanan müşterilerin memnuniyetini etkileyen faktörlerin müşterilerin cinsiyetine göre farklılık gösterip göstermediği Mann-Whitney U testi ile sınanmıştır. Bu test için oluşturulan hipotezler aşağıda yer almaktadır. Çizelge 3.10'da Mann-Whitney U testi sonuçları verilmektedir. 
Hod: Van Ferit Melen Havalimanı'nda müşteri memnuniyetini etkileyen sosyal alan faktörü müşterilerin cinsiyetine göre anlamlı farklılık göstermemektedir.

H1d: Van Ferit Melen Havalimanı'nda müşteri memnuniyetini etkileyen sosyal alan faktörü müşterilerin cinsiyetine göre anlamlı farklılık göstermektedir.

$H_{0 e}$ : Van Ferit Melen Havalimanı'nda müşteri memnuniyetini etkileyen fiziksel şartlar faktörü müşterilerin cinsiyetine göre anlamlı farklılık göstermemektedir.

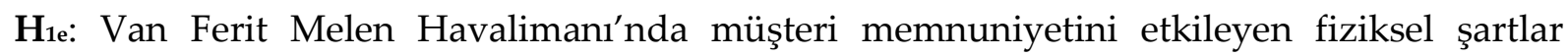
faktörü müşterilerin cinsiyetine göre anlamlı farklılık göstermektedir.

Hof: Van Ferit Melen Havalimanı'nda müşteri memnuniyetini etkileyen zaman faktörü müşterilerin cinsiyetine göre anlamlı farklılık göstermemektedir.

H1f: Van Ferit Melen Havalimanı'nda müşteri memnuniyetini etkileyen zaman faktörü müşterilerin cinsiyetine göre anlamlı farklılık göstermektedir.

Hog: Van Ferit Melen Havalimanı'nda müşteri memnuniyetini etkileyen uçuş işlemleri faktörü müşterilerin cinsiyetine göre anlamlı farklılık göstermemektedir.

$\mathbf{H}_{1 \mathrm{~g}}$ : Van Ferit Melen Havalimanı'nda müşteri memnuniyetini etkileyen uçuş işlemleri faktörü müşterilerin cinsiyetine göre anlamlı farklılık göstermektedir.

$H_{0 h}$ : Van Ferit Melen Havalimanı'nda müşteri memnuniyetini etkileyen personel faktörü müşterilerin cinsiyetine göre anlamlı farklılık göstermemektedir.

$H_{1 h}$ : Van Ferit Melen Havalimanı'nda müşteri memnuniyetini etkileyen personel faktörü müşterilerin cinsiyetine göre anlamlı farklılık göstermektedir.

Çizelge 3.50. Mann-Whitney - U testi sonuçları

\begin{tabular}{lll}
\hline Faktörler & Test istatistiği & Olasılık değeri $(\mathbf{p})$ \\
\hline Faktör 1 & $\mathrm{U}=11208,5$ & 0,990 \\
& $\mathrm{Z}=-0,013$ & \\
Faktör 2 & $\mathrm{U}=10651$ & 0,448 \\
& $\mathrm{Z}=--0,759$ & \\
Faktör 3 & $\mathrm{U}=10773,5$ & 0,551 \\
& $\mathrm{Z}=-0.596$ & \\
Faktör 4 & $\mathrm{U}=11035,5$ & 0,807 \\
& $\mathrm{Z}=-0,245$ & \\
Faktör 5 & $\mathrm{U}=11100$ & 0,872 \\
& $\mathrm{Z}=-0,161$ & \\
\hline
\end{tabular}

Çizelge 3.10 incelendiğinde olasılık değerleri $p>0,05$ olduğu için sıfır hipotezi reddedilememektedir. Bu durumda Van Ferit Melen Havaalanı'nda müşterilerin memnuniyetini etkileyen faktörlerin tümünün cinsiyete göre farklılık göstermediği sonucuna ulaşılmıştır.

\subsubsection{Sıralı lojistik regresyon analizi sonuçları}

Ankete katılan bireylere "Van Ferit Melen Havalimanı'ndan kaç kere seyahat ettiniz?" sorusu yöneltilmiş ve yanıtlar kategorik olarak verilmiştir. Sıralı lojistik regresyon analizi için bağımlı değişken olarak ankete katılan bireylerin Van Ferit Melen Havalimanı'ndan 
seyahat sayıları seçilmiştir. Bağımlı değişkenin kategorileri "Yılda 1 kez", "Ayda 1 kez", "Ayda 2-3 kez" ve "Haftada 1 kez" olmak üzere sıralanabilir şekilde oluşturulmuştur. "Haftada 1 kez" kategorisi ankete katılan bireyler tarafından hiç işaretlenmediği için bağımlı değişken 3 kategorili bir değişken halini almıştır.

Sıralı lojistik regresyon analizinde kullanılacak bağımsız değişkenler için nicel değişkenler Kruskal-Wallis testi ile nitel değişkenler ise Ki-Kare Bağımsızlık testi ile belirlenmiştir. Nicel bağımsız değişkenleri belirlemek için Kruskal-Wallis testi sonuçları Çizelge 3.11'de gösterilmektedir.

Çizelge 3.11. Nicel değişkenler için Kruskal-Wallis testi sonuçları

\begin{tabular}{|c|c|c|}
\hline Bağımsız Değişkenler (Nicel değişkenler) & Test İstatistiği & Olasılık Değeri (p) \\
\hline Yaş & 15,220 & $0,000^{* * *}$ \\
\hline Faktör 1 & 4,348 & 0,114 \\
\hline Faktör 2 & 6,184 & $0,045^{* *}$ \\
\hline Faktör 3 & 0,164 & 0,921 \\
\hline Faktör 4 & 1,131 & 0,568 \\
\hline Faktör 5 & 2,852 & 0,240 \\
\hline
\end{tabular}

Çizelge 3.11 incelendiğinde nicel değişkenlerden "Yaş" ve "Faktör 2 (fiziksel şartlar faktör skoru)" değişkenlerinin istatistiksel olarak anlamlı olduğu sonucuna ulaşılmıştır ( $<<0,05)$. Nitel bağımsız değişkenleri belirlemek için Ki-Kare Bağımsızlık testi sonuçları Çizelge 3.12 'de gösterilmektedir.

Çizelge 3.62. Nitel değişkenler için Ki-Kare bağımsızlık testi sonuçları

\begin{tabular}{|c|c|c|}
\hline Bağımsız Değişkenler (Nitel değişkenler) & Test İstatistiği & Olasılık Değeri (p) \\
\hline Cinsiyet & 6,591 & $0,037^{* *}$ \\
\hline Meslek & 28,815 & $0,001^{* * *}$ \\
\hline Gelir durumu & 42,434 & $0,000^{* * *}$ \\
\hline Eğitim durumu & 18,400 & $0,005^{* * *}$ \\
\hline Seyahat sıklığ 1 & 181,599 & $0,000 * * *$ \\
\hline
\end{tabular}

Çizelge 3.12 incelendiğinde nitel değişkenlerden "Cinsiyet", "Meslek", "Gelir durumu", "Eğitim durumu" ve "Seyahat sıklığı" değişkenlerinin istatistiksel olarak anlamlı olduğu tespit edilmiştir. Hem nicel hem de nitel değişkenlerden anlamlı olan değişkenler sıralı lojistik regresyon analizinde bağımsız değişkenler olarak belirlenmiştir.

Sıralı lojistik regresyon analizi için öncelikle paralel doğrular varsayımı test edilmiştir. Çizelge 3.13'te paralel doğrular varsayımına ait testin sonuçları verilmektedir. Paralel doğrular varsayımı testi için hipotezler aşağıdaki şekilde oluşturulmaktadır.

$\mathbf{H}_{0}$ : Modelin regresyon katsayıları, bağımlı değişkenin her kategorisinde aynıdır.

H1: Modelin regresyon katsayıları, bağımlı değişkenin en az bir kategorisinde farklıdır.

Çizelge 3.73. Paralel doğrular varsayımı testine ilişkin sonuçlar

\begin{tabular}{|c|c|c|c|c|c|}
\hline Model & -2 Log Olabilirlik & $\begin{array}{l}\text { Ki-Kare } \\
\text { İstatistiği }\end{array}$ & Test & $\begin{array}{l}\text { Serbestlik } \\
\text { Derecesi }\end{array}$ & $\begin{array}{l}\text { Olasilık } \\
\text { (p) }\end{array}$ \\
\hline Yokluk Hipotezi & 365,427 & & & & \\
\hline General & 350,396 & 15,031 & & 17 & 0,593 \\
\hline
\end{tabular}

Paralel doğrular varsayımı modelde tahmin edilen regresyon katsayılarının bağımlı değişkenin tüm kategorilerinde aynı değere sahip olmalarını varsaymaktadır. Bu bağlamda 
Çizelge 3.13 incelendiğinde $\mathrm{p}>0,05$ olduğu için sıfır hipotezi reddedilemez. Bu durumda modelin regresyon katsayıları, bağımlı değişkenin her kategorisinde aynıdır. Yani paralel doğrular varsayımının sağlandığı sonucuna ulaşılmıştır.

Paralel doğrular varsayımının sağlandığı tespit edildikten sonra modelin uyum iyiliği ölçülerinin incelenmesi gerekmektedir. Çizelge 3.14'te uyum iyiliği ölçütlerinden olan Pearson ve Sapma istatistiklerine ait sonuçlar yer almaktadır.

Ho: Veriler modele uygunluk göstermektedir.

H1: Veriler modele uygunluk göstermemektedir.

Çizelge 3.84. Test istatistikleri ile uyum iyiliği sonuçları

\begin{tabular}{llll}
\hline & Ki-Kare & Serbestlik Derecesi & Olasılık Değeri (p) \\
\hline Pearson & 583,021 & 543 & 0,109 \\
Sapma & 365,427 & 543 & 1,000 \\
\hline
\end{tabular}

Çizelge 3.14 incelendiğinde her iki test istatistiğine ait olasılık değerleri $0,05^{\prime}$ ten büyük olduğu görülmektedir. Bu durumda sıfır hipotezi reddedilemez $p(>0,05)$. Yani veriler modele uygunluk göstermektedir.

Sıralı lojistik regresyon model için gerekli varsayımlar sağlandıktan sonra model tahmin edilmelidir (Hayat \& Sözen Özden, 2021). Çizelge 3.15'de sıralı lojistik regresyon modeline ait tahmin sonuçları gösterilmektedir. Çizelge 3.15'de odds oranı tahmin edilen katsayı değerlerinin eksponansiyeli (e üssü) alınarak hesaplanmıştır. Odds oranları sıralı lojistik modeli yorumlayabilmek için hesaplanmıştır.

Çizelge 3.15. Sıralı lojistik regresyon modeli tahmin sonuçları

\begin{tabular}{|c|c|c|c|c|}
\hline Değişkenler & Katsayı & Odds Oranı & Test istatistiği & Olasılık değeri (p) \\
\hline Yaş & 0,035 & 1,036 & 5,846 & $0,016^{* *}$ \\
\hline Faktör 2 & 0,057 & 1,059 & 0,127 & 0,721 \\
\hline \multicolumn{5}{|l|}{ Gelir Durumu } \\
\hline 1:1000-1999 & $-1,059$ & 0,347 & 2,768 & $0,096^{*}$ \\
\hline 2:2000-2999 & $-0,909$ & 0,403 & 3,318 & $0,069^{*}$ \\
\hline 3:3000-3999 & $-0,179$ & 0,836 & 0,125 & 0,724 \\
\hline \multicolumn{5}{|l|}{ Meslek } \\
\hline 1: Ücretli çalışan & 0,956 & 2,601 & 4,936 & $0,026^{* *}$ \\
\hline 2: İşyeri sahibi & 0,928 & 2,529 & 2,882 & $0,090^{*}$ \\
\hline 3: Emekli & 1,479 & 4,389 & 3,863 & $0,049 * *$ \\
\hline 4: Öğrenci & 1,865 & 6,456 & 7,386 & $0,007^{* * *}$ \\
\hline 5: İşsiz & 2,009 & 7,459 & 4,021 & $0,045^{* *}$ \\
\hline \multicolumn{5}{|l|}{ Eğitim durumu } \\
\hline 1: İlkokul & $-1,886$ & 0,152 & 2,541 & 0,111 \\
\hline 2: Ortaokul & $-1,139$ & 0,320 & 5,011 & $0,025^{* *}$ \\
\hline 3: Lise & $-0,956$ & 0,384 & 7,293 & $0,007^{* * *}$ \\
\hline \multicolumn{5}{|l|}{ Seyahat sıklığı } \\
\hline 1: Yılda $1 \mathrm{kez}$ & $-4,188$ & 0,015 & 21,158 & $0,000^{* * *}$ \\
\hline 2: Ayda 1 kez & $-0,323$ & 0,724 & 0,204 & 0,651 \\
\hline 3: Ayda 2-3 kez & 0,719 & 2,052 & 1,083 & 0,298 \\
\hline \multicolumn{5}{|l|}{ Cinsiyet } \\
\hline 1: Erkek & 0,139 & 1,149 & 0,228 & 0,633 \\
\hline
\end{tabular}


"Eğitim durumu" değişkeni için temel düzey "Üniversite" olarak belirlenmiştir. "Seyahat sıklığı" değişkeni için temel düzey "Her gün” olarak belirlenmiştir. Cinsiyet değişkeni için ise temel düzey "Kadın" olarak belirlenmiştir. Analiz sonucunda "Cinsiyet" ve "Faktör 2 (Fiziksel şartlar faktör skoru)" değişkenlerinin istatistiksel olarak anlamlı olmadiğı tespit edilmiştir. Çizelge 3.15' de istatistiksel olarak anlamlı değişkenler önem düzeyine göre "**" ile belirtilmiştir. İstatistiksel olarak anlamlı olduğu tespit edilen değişkenlere ait odds oranları aşağıdaki şekilde yorumlanmıştır.

Bireyin yaşının 1 yaş artması, Van Ferit Melen Havalimanı'ndan seyahat etme düzeyini diğer bireylere göre 1,036 kat arttırmaktadır $(\mathrm{p}<0,05)$.

Gelir durumu 1000-1999 TL arasında olan bireylerin gelir durumu 4000 TL ve üstünde olan bireylere göre, Van Ferit Melen Havalimanı'ndan seyahat etme düzeyleri 0,347 kat daha az olmaktadir $(\mathrm{p}<0,10)$

Gelir durumu 2000-2999 TL arasında bireylerin gelir durumu 4000 TL ve üstünde olan bireylere göre, Van Ferit Melen Havalimanı'ndan seyahat etme düzeyleri 0,403 kat daha az olmaktadır $(\mathrm{p}<0,10)$.

Ücretli çalışan bireylerin diğer meslek gruplarındaki bireylere göre, Van Ferit Melen Havalimanı'ndan seyahat etme düzeyleri 2,601 kat daha fazla olmaktadır $(p<0,05)$.

İş yeri sahibi olan bireylerin diğer meslek gruplarındaki bireylere göre, Van Ferit Melen Havalimanı'ndan seyahat etme düzeyleri 2,529 kat daha fazla olmaktadır $(p<0,10)$

Emekli bireylerin diğer meslek gruplarındaki bireylere göre, Van Ferit Melen Havalimanı'ndan seyahat etme düzeyleri 4,389 kat daha fazla olmaktadır $(p<0,05)$.

Öğrencilerin diğer meslek gruplarındaki bireylere göre, Van Ferit Melen Havalimanı'ndan seyahat etme düzeyleri 6,456 kat daha fazla olmaktadır $(\mathrm{p}<0,01)$

İşsiz bireylerin diğer meslek gruplarındaki bireylere göre, Van Ferit Melen Havalimanı'ndan seyahat etme düzeyleri 7,459 kat daha fazla olmaktadır $(\mathrm{p}<0,05)$.

Ortaokul mezunu bireylerin üniversite mezunu bireylere göre, Van Ferit Melen Havalimanı'ndan seyahat etme düzeyleri 0,320 kat daha az olmaktadır $(p<0,05)$

Lise mezunu bireylerin üniversite mezunu bireylere göre, Van Ferit Melen Havalimanı'ndan seyahat etme düzeyleri 0,384 kat daha az olmaktadır $(\mathrm{p}<0,01)$

Yılda 1 kez seyahat eden bireylerin her gün seyahat eden bireylere göre, Van Ferit Melen Havalimanı'ndan seyahat etme düzeyleri 0,015 kat daha az olmaktadır $(\mathrm{p}<0,01)$.

Tüm bu sonuçlar altında Van Ferit Melen Havalimanı'ndan seyahat eden bireylerin memnuniyetini etkileyen faktörlerin başında gelir ve eğitim durumlarının önemli bir yere sahip olduğu söylenebilmektedir. Bireylerin gelir durumu arttıkça Van Ferit Melen Havalimanı'ndan seyahat etme düzeylerinin de arttığı görülmektedir. Eğitim durumu değişkeninin de Van Ferit Melen Havalimanı'ndan seyahat etme düzeyi üzerinde önemli etkisinin olduğu sonucuna ulaşılmıştır. Bireylerin eğitim durumu arttıkça Van Ferit Melen Havalimanı'ndan seyahat etme düzeylerinin de arttığı görülmektedir. Meslek gruplarının da Van Ferit Melen Havalimanı'ndan seyahat etme durumu üzerinde önemli etkisinin olduğu görülmektedir. 


\section{Tartışma ve Sonuç}

Havaalanları yapısal yönleri itibariyle durağanlıktan uzak ve oldukça hareketli yerler olarak bilinmektedir. Bu hareketlilik havaalanlarının yapıları ve taşımacılık uygulamalarında kullanılan sistemlerin doğal bir getirisi olarak değerlendirilebilir. Nitekim havayolu taşımacılığı hem güncel gelişmeler hem de yapı itibariyle teknolojik gelişmeleri yakından takip etmek ve bununla birlikte yönetim bilgi sistemlerinden yararlanılması gereken yapılar olarak ön plana çıkmaktadır.

Her işletmede olduğu gibi havaalanlarında da müşterilerin memnuniyetinin sağlanması hem işletmenin sürekliliğinin sağlanması hem de mevcut yapıların geliştirilmesi için büyük önem taşımaktadır.

İşletmeler açısından bu denli önemli olan müşteri memnuniyetinin sağlanması hususu havaalanlarının karmaşık yapısı ile bağlantılı olarak pek çok faktörden etkilenen bir yapı olarak değerlendirilebilir. Nitekim havaalanlarında bilgi teknolojilerinin kullanımına ağırlık verilmesi, insan kaynakları açısından yürütülen hizmetlere dair güncellemeler yapılması ve mevcut havayolu taşıma şirketleri arasındaki rekabetlerden kaynaklı olarak müşterilere sunulan hizmetler konusunda hem ulusal hem de uluslararası standartlara göre hareket edilmesi gibi hususlar, müşteri memnuniyetinin sağlanması noktasında bir zorunluluk olarak karşımıza çıkmaktadır.

Müşteri memnuniyetinin sağlanması hususunun işletmeler açısından hayati önem taşımasından hareketle Van Ferit Melen Havalimanı'nda müşteri memnuniyetinin sağlanması konusunu ele aldığımız çalışmamızda yaptığımız araştırmalar sonucunda müşteri memnuniyeti konusunda yalnızca havalimanında sunulan hizmetlerin değil, müşterilerin belirli birtakım özelliklerinin de etkili olduğu gibi genel bir sonuca ulaştı̆̆ımızdan öncelikli olarak bahsetmemiz gerekmektedir. Bu konuda araştırmamızın sonuçlarına dayanarak hava yolu müşterilerinin memnuniyetini etkileyen temel faktörlerin başında müşterilerin ekonomik durumları, eğitim durumları gibi hususların geldiğini söylememiz mümkündür. Bununla birlikte müşterilerin ekonomik durumlarının iyileşmesi ile doğru orantılı olarak hava yolu taşımacılığını kullanım oranlarının arttığı ve bu doğrultuda da Van Ferit Melen Havalimanı'nda seyahat etme düzeylerinin artış gösterdiği de tespit edilmiştir. Eğitim durumu ile müşteri memnuniyeti arasındaki ilişkinin Van Ferit Melen Havalimanı'na yansıma düzeyi ise yine havayolu taşımacılığının kullanım sıklığının artması şeklinde kendini göstermektedir. Buna göre, eğitim düzeyi arttıkça havayolu kullanımının arttığını, eğitim düzeyi azaldıkça havayolu kullanımının azaldığı da yapılan araştırmada ulaşılan sonuçlar arasındadır. Bu husus esasında direkt olarak eğitim durumu ile ilgili olarak ele alınsa da yalnızca eğitim durumuna bağlı olarak değerlendirmek eksik bir değerlendirme olacaktır. Nitekim bahsedilen hususun da bireylerin eğitim durumundan kaynaklı olarak ekonomik gelir düzeylerindeki artışla da bir arada değerlendirilmesi mümkündür. Eğitim düzeyi yükselen bireylerin iş hayatında daha aktif bir yapıya sahip olmaları onların ekonomik anlamdaki düzeylerini de daha iyi bir seviyeye taşımakta ve bu sayede bahsedilen çerçeve kapsamına giren bireyler havayolu taşımacılığını daha fazla kullanabilmektedirler.

Tüm bu sonuçlar altında Van Ferit Melen Havalimanı'ndan seyahat eden bireylerin memnuniyetini etkileyen faktörlerin başında gelir ve eğitim durumlarının önemli bir yere 
sahip olduğu söylemememiz mümkündür. Bireylerin gelir durumu arttıkça Van Ferit Melen Havalimanı'ndan seyahat etme düzeylerinin de arttı̆̆ görülmektedir.

Meslek gruplarının da Van Ferit Melen Havalimanı'ndan seyahat etme durumu üzerinde önemli etkisinin olduğu görülmektedir.

Van Ferit Melen Havalimanı'nda müşteri memnuniyeti üzerinde etkili olan bir diğer husus ise müşterilerin meslekleri olarak tespit edilmiştir. Bu açıdan belirli meslek gruplarına dahil olan bireylerin ulaşım faaliyetlerinde havayolu taşımacılığını tercih etme oranlarının daha yüksek olduğu görülmektedir $\mathrm{ki}$ bu durumda esasında yalnızca mesleki yapiyla değerlendirildiğinde eksik bir değerlendirmeye sebep olacaktır. Nitekim bireyler yine eğitim seviyeleri ile doğru orantılı olarak daha iyi mesleklerde görev alabilecekleri için ulaşım faaliyetlerinde havayolunu tercih edebilmektedirler. Bununla birlikte meslek grupları açısından üst düzey mesleklerde görev alan veya daha iyi meslek gruplarında görev alan bireylerin gelir düzeyleri de artacağı için bu da ulaşım faaliyetlerinde havayolu tercihini etkileyen bir faktör olarak ön plana çıkacaktır. Bu açıdan her ne kadar münferit bir yapı olarak ele alınsa da bireylerin mensup oldukları mesleki yapıların hem eğitim hem de bireyin gelir düzeyi ile bir arada değerlendirilmesi gereken bir faktör olduğunu söylememiz mümkündür.

\section{Araştırmacıların Katkı Oranı Beyanı / Researchers' Contribution Rate Statement Yazarlar bu çalışmaya eşit şekilde katkı sağladıklarını beyan etmiştir. \\ The authors declare that they have contributed equally to this article.

\begin{abstract}
Araştırmacıların Çatışma Beyanı / Researchers'Conflict of Interest Statement Yazarlar, bu çalışmada potansiyel bir çıkar çatışması olmadığını beyan etmişlerdir. The authors declare that there is no potential conflict of interest in this study.
\end{abstract}

\section{KAYNAKÇA}

2920 Sayılı Türk Sivil Havacılık Kanunu, Resmî Gazete. 18196; 19 Ekim 1983.

Altunışık, R., Coşkun, R., Bayraktaroğlu, S. \& Yıldırım, E. (2012). Sosyal Bilimlerde Araştırma Yöntemleri: Spss Uygulamalı, (Geliştirilmiş 7.Baskı), Sakarya Kitabevi, Adapazarı.

Burucuoğlu, M., 2011. Müşteri Memnuniyeti ve Sadakatini Arttırmada Müşteri Şikayetleri Yönetiminin Etkinliği: Bir Örnek Olay İncelemesi (yüksek lisans tezi). Karamanoğlu Mehmetbey Üniversitesi, Sosyal Bilimler Enstitüsü, Karaman.

Gerede, E., 2002. Havayolu Taşımacılığında Küreselleşme ve Havayolu İşbirlikleri - THY AO'da Bir Uygulama (doktora tezi, yayınlanmamış). Anadolu Üniversitesi SBE, Eskişehir.

Hayat, E. \& Sözen Özden, A. (2021). Genelleştirilmiş Sıralı Lojistik Regresyon Analizi ile Bireylerin Mutluluk Düzeylerine Etki Eden Faktörlerin Belirlenmesi . OPUS International Journal of Society Researches , 18 (40) , 2288-2316 . DOI: 10.26466/opus.891886 
İslamoğlu, A. H. , Alnıaçık, Ü. (2014). Sosyal Bilimlerde Araştırma Yöntemleri, (4. Bs.) İstanbul : Beta Basım Yayım Dağıtım A.Ş.

Kavzoğlu, T., Yılmaz, E., 2005. Atatürk havalimanı bilgi sistemi. TMMOB Harita ve Kadastro Mühendisleri Odası 10. Türkiye Harita Bilimsel ve Teknik Kurultayı, 28 Mart - 1 Nisan 2005, Ankara.

Kaya, E., 2000. Havaalanlarında Fiyatlandırma Açısından Muhasebe Bilgi Sistemi. T.C. Anadolu Üniversitesi Yayınları, 1204, Eskişehir.

Kaya, E., 2005. Havaalanlarında Yap İşlet Devret Uygulamaları: Antalya ve Atatürk Havalimanlarındaki Uygulamaların Değerlendirilmesi. T.C. Anadolu Üniversitesi Yayınları, 1649, Eskişehir.

Kesikbaş, E., 2006. Havaalanı Terminal İşletmeciliği ve Konya Havaalanı Uygulaması (yüksek lisans tezi). Dumlupınar Üniversitesi, Sosyal Bilimler Enstitüsü, Kütahya.

Koçel, T., 1995. İşletme Yöneticiliği: Yönetici Geliştirme, Organizasyon ve Davranış. Beta Basım Yayım Dağıtım, İstanbul.

Koçel, T., 2007. İşletme Yöneticiliği. Arıkan Basım, İstanbul.

Kuyucak, F., 2007. Havaalanlarında Değer Odaklı Yönetim Yönelimli Bilgi Sistemlerinin Kullanılması ve Atatürk Havalimanı Terminal İşletmeciliği Uygulaması (doktora tezi, yayınlanmamış). Anadolu Üniversitesi, Sosyal Bilimler Enstitüsü, Eskişehir.

Odabaşı, Y., 2003. Satış ve Pazarlamada Müşteri İlişkileri Yönetimi. Sistem Yayıncılık, İstanbul.

Okumuş, A., Asil, H., 2007. Havayolu taşımacılığında yerli ve yabancı yolcuların memnuniyet düzeylerine göre beklentilerinin incelenmesi. Kocaeli Üniversitesi Sosyal Bilimler Enstitüsü Dergisi, 13 (1): 152 - 175.

Özkoç, O. Z., 2018. Havaalanı Müşteri Memnuniyetini Belirleyen Faktörlerin Araştırılması: Konya Havalimanı Örneği (yüksek lisans tezi), KTO Karatay Üniversitesi, Sosyal Bilimler Enstitüsü, Konya.

Seyidoğlu, H., 2009. Bilimsel Araştırma ve Yazma El Kitabı. Güzem Can Yayınları, İstanbul.

Şengür, F. K. (2017). Havaalanı İşletmeciliğinde Yeni Eğilimler: Türkiye Üzerine Bir Değerlendirme . Uluslararası Yönetim İktisat ve İşletme Dergisi, 13 (4) , 751-766 . DOI: 10.17130/ijmeb.2017433406

Tavmergen, İ. P., 2002. Turizm Sektöründe Kalite Yönetimi. Seçkin Yayıncıllk, Ankara.

Türkiye Odalar ve Borsalar Birliği, Türkiye Sivil Havacılık Meclisi Raporu 2014. 